\title{
Notes
}

\section{Source Abbreviations}

ABRI Angkatan Bersenjata Republik Indonesia

AFP Agence France Presse

AJI Aliansi Jurnalis Independen

AP Associated Press

AT Asia Times

AWSJ Asian Wall Street Journal

CPJ Committee to Protect Journalists

DJ Dow Jones

FEER Far Eastern Economic Review

ICJ International Commission of Jurists

IHT International Herald Tribune

IO Indonesian Observer

IPS International Press Service

ISAI Institut Studi Arus Informasi

JG Jakarta Globe

JOMC Joint Operations Media Center (General Election Commission)

JP Jakarta Post

LAT Los Angeles Times

LSPP Lembaga Studi Pers \& Pembangunan

MI Media Indonesia

NYT New York Times

SCMP South China Morning Post

SMH Sydney Morning Herald

SP Suara Pembaruan

ST Straits Times

TN The Nation (New York)

WP Washington Post

WSJ Wall Street Journal

\section{INTRODUCTION}

1. Susanto Pujomartono, "Pers Indonesia Pasca Soeharto," in Reformasi Media Massa, ed. Ery Sutrisno (Jakarta: AJI, 1998), 36-38. Unless otherwise noted, all translations are my own.

2. Lukas Luwarso, "Wajah Media Massa Kita," in Sutrisno, Reformasi Media Massa, 26.

3. Ibid., 29.

4. Ibid., 30-31.

5. Louise Williams, "Poor Little Rich Kids," SMH, October 24, 1998.

6. Samuel P. Huntington, The Third Wave: Democratization in the Late Twentieth Century (Norman: University of Oklahoma Press, 1991), 266-67. 
7. Huntington, Third Wave; Scott Mainwaring, Guillermo O'Donnell, and J. Samuel Valenzuela, introduction to Issues in Democratic Consolidation: The New South American Democracies in Comparative Perspective, ed. Scott Mainwaring, Guillermo O’Donnell, and J. Samuel Valenzuela (Notre Dame, IN: University of Notre Dame Press, 1992), 4.

8. Huntington, Third Wave, 15, 209-79; Robert A. Dahl, Polyarchy: Participation and Observation (New Haven, CT: Yale University Press, 1971), 203.

9. Juan J. Linz, introduction to The Breakdown of Democratic Regimes, ed. Juan J. Linz and Alfred Stepan (Baltimore: Johns Hopkins University Press, 1978), 3.

10. Scott Shane, Dismantling Utopia: How Information Ended the Soviet Union (Chicago: Ivan R. Dee, 1994); Kuldip R. Rampal, "Press and Political Liberalization in Taiwan," Journalism Quarterly 71, no. 3 (1994): 637-51; Gladys Ganley, Unglued Empire: The Soviet Experience with Communications Technologies (Norwood, NJ: Ablex, 1996); Gary D. Rawnsley and Ming-yeh T. Rawnsley, "Regime Transition and the Media in Taiwan," in Democratization and the Media, ed. Vicky Randall, 106-24 (London: Frank Cass, 1998).

11. Mainwaring, O'Donnell, and Valenzuela, introduction, 4.

12. See Krishna Sen and David T. Hill, eds., Politics and the Media in Twenty-First Century Indonesia: Decade of Democracy (Abingdon, UK: Routledge, 2011); Mercy Ette, "Agent of Change or Stability? The Nigerian Press Undermines Democracy," Harvard International Journal of Press/ Politics 5, no. 3 (2001): 67-86; Richard Gunther, Jose Ramon Montero, and Jose Ignacio Wert, "The Media and Politics in Spain: From Dictatorship to Democracy," in Democracy and the Media: A Comparative Perspective, ed. Richard Gunther and Anthony Mughan, 28-84 (Cambridge: Cambridge University Press, 2000); Karl Jakubowicz, "Media in Transition: The Case of Poland," in Media Reform: Democratizing the Media, Democratizing the State, ed. Monroe E. Price, Beata Rozumilowicz, and Stefaan G. Verhulst, 203-31 (London: Routledge, 2002); G. Hyden and M. Leslie, "Communications and Democratization in Africa," in Media and Democracy in Africa, ed. G. Hyden, M. Leslie, and F. Ogundimu, 1-28 (New Brunswick, NJ: Transaction, 2002); E. O. Ojo, "The Mass Media and the Sustainable Democratic Values in Nigeria: Possibilities and Limitations," Media, Culture \& Society 25, no. 6 (2003): 821-40; Matthew Loveless, "Media Dependency: Mass Media as Sources of Information in the Democratizing Countries of Central and Eastern Europe," Democratization 15, no. 1 (2008): 162-83; Aje-Ori Anna Agbese, The Role of the Press and Communication Technology in Democratization: The Nigerian Story (New York: Routledge, 2007); Marta Dyczok, "Do the Media Matter? Focus on Ukraine," in Media, Freedom and Democracy: The Post-Communist Experience, ed. Marta Dyczok and Oxana Gaman-Golutvina, 17-41 (Bern: Peter Lang, 2009); Zola Maddison, "Information's Role in Emerging Democratic Societies-the Case of Indonesia," Information for Social Change 25 (Summer 2007): 26-32; Robert B. Horwitz, Communication and Democratic Reform in South Africa (Cambridge: Cambridge University Press, 2006); Katrin Voltmer, The Media in Transitional Democracies (Cambridge: Polity, 2013); Philip N. Howard and Muzammil M. Hussain, Democracy's Fourth Wave? Digital Media and the Arab Spring (Oxford: Oxford University Press, 2012); Krishna Sen and Terence Lee, eds., Political Regimes and the Media in Asia (New York: Routledge, 2008); Angela Romano, Politics and the Press in Indonesia: Understanding an Evolving Political Culture (New York: Routledge, 2003).

13. Adam Przeworski, Democracy and the Market: Political and Economic Reforms in Eastern Europe and Latin America (Cambridge: Cambridge University Press, 1991), 14.

14. Andreas Schedler, The Politics of Uncertainty: Sustaining and Subverting Electoral Authoritarianism (New York: Oxford University Press, 2013), 1.

15. Adam Przeworski, "Some Problems in the Study of Transition to Democracy," in Transitions from Authoritarian Rule, ed. Guillermo O'Donnell, Philippe C. Schmitter, and Laurence Whitehead (Baltimore: Johns Hopkins University Press, 1986), 58.

16. Ibid., 57.

17. Huntington, Third Wave.

18. Silvio R. Waisbord, Watchdog Journalism in South America: News, Accountability, and Democracy (New York: Columbia University Press, 2000), 243.

19. Vicky Randall, introduction to Democratization and the Media, 5; Sheila S. Coronel, "The Role of the Media in Deepening Democracy," United Nations Public Administration Network, 2003, http://unpan1.un.org/intradoc/groups/public/documents/un/unpan010194.pdf.

20. Przeworski, Democracy and the Market, 26.

21. Przeworski, "Some Problems."

22. Randall, introduction, 3. 
23. Merlyna Lim, "The Internet, Social Networks, and Reform in Indonesia," in Asia Encounters the Internet, ed. K. C. Ho, R. Kluver, and K. Yang (London: Routledge, 2003), 113-28; Jeffrey Winters, "The Political Impact of New Information Sources and Technologies in Indonesia," Gazette: The International Journal for Communication Studies 64, no. 2 (2002): 109-19.

24. Przeworski, Democracy and the Market, 13.

25. See Andie Tucher and Dan Bischoff, "Scorned in an Era of Triumphant Democracy," Media Studies Journal 9, no. 3 (1995): 160.

26. See T. E. Patterson, "Of Polls, Mountains: U.S. Journalists and Their Use of Election Surveys," Public Opinion Quarterly 69, no. 5 (2005): 716-24; Jay Rosen, "Brainless: The Media and Horse Race Journalism," Pacific Free Press, January 20, 2008.

27. See James M. Fallows, Breaking the News: How the Media Undermine American Democracy (New York: Vintage Books, 1997), 53.

28. Lanny Davis, Scandal: How "Gotcha" Politics Is Destroying America (Basingstoke, UK: Palgrave Macmillan, 2006), 5-6.

29. Quoted in Vicky Randall, "The Media and Democratization in the Third World," Third World Quarterly 14, no. 3 (1993): 640.

30. Quoted in Hervin Saputra, "If Internet and Media Compete for Ripping Up Privacy," trans. Rosmi Julitasari, VHR Media.com, accessed August 7, 2010, http://www.vhrmedia.com/ If-Internet-and-Media-Compete-for-Ripping-Up-Privacy-focus4621.html.

31. Howard Tumber and Silvio R. Waisbord, "Introduction: Political Scandals and Media across Democracies, Volume I," American Behavioral Scientist 47, no. 8 (2004): 1031-32, 1035.

32. Alastair Bellany, The Politics of Court Scandal in Early Modern England: News Culture and the Overbury Affair, 1603-1660 (Cambridge: Cambridge University Press, 2002), 74-135, 261-78.

33. Sarah Maza, Private Lives and Public Affairs: The Causes Célèbres of Prerevolutionary France (Berkeley: University of California Press, 1993), 38.

34. Marcus Daniel, Scandal and Civility: Journalism and the Birth of American Democracy (New York: Oxford University Press, 2009).

35. Alex Hall, Scandal, Sensation and Social Democracy: The SPD Press and Wilhelmine Germany 1890-1914 (Cambridge: Cambridge University Press, 1977).

36. Chappell H. Lawson, Building the Fourth Estate: Democratization and the Rise of a Free Press in Mexico (Berkeley: University of California Press, 2002), 9.

37. Miklós Sükösd, "Democratic Transformation and the Mass Media in Hungary: From Stalinism to Democratic Consolidation," in Gunther and Mughan, Democracy and the Media, $146-47$.

38. See Lim, "Internet, Social Networks, and Reform," 113-28.

39. Pippa Norris, A Virtuous Circle: Political Communications in Post-industrial Democracies (Cambridge: Cambridge University Press, 2000).

40. Larry Diamond, Developing Democracy: Toward Consolidation (Baltimore: Johns Hopkins Press, 1999), 162.

41. Benedict Anderson, Imagined Communities: Reflections on the Origin and Spread of Nationalism (London: Verso, 1991), 35n63.

42. Sharif Abdel Kouddous, "After Mubarak, Fighting for Press Freedom in Egypt," TN, June 20, 2011.

43. See Daniel Lynch, After the Propaganda State: Media, Politics, and "Thought Work" in Reformed China (Stanford, CA: Stanford University Press, 1999).

\section{Origins of Media Controls}

1. Saafroedin Bahar, Ananda B. Kusuma, and Nannie Hudawati, eds., Risalah Sidang Badan Penyelidik Usaha-Usaha Persiapan Kemerdekaan Indonesia (BPUPKI), Panitia Persiapan Kemerdekaan Indonesia (PPKI) 28 Mei 1945-22 Agustus 1945 (Jakarta: Sekretariat Negara Republik Indonesia, 1995).

2. Quoted ibid., 71.

3. Quoted ibid., 258, 79.

4. Peter Burns, The Leiden Legacy: Concepts of Law in Indonesia (Leiden: KITLV, 2004), 244-46.

5. Ibid.

6. See David Reeve, "The Corporatist State: The Case of Golkar," in State and Civil Society in Indonesia, ed. Arief Budiman, 151-76 (Melbourne: Centre for Southeast Asian Studies, 
Monash University, 1990); David Bourchier, "Totalitarianism and the 'National Personality," in Imagining Indonesia: Cultural Politics \& Political Culture, ed. Jim Schiller and Barbara MartinSchiller, 157-85 (Athens: Ohio University Center for International Studies, 1997).

7. Bahar, Kusuma, and Hudawati, Risalah, 260-61.

8. Quoted ibid., 35.

9. Ibid., 36-37, 17.

10. Website of the Embassy of the Republic of Indonesia, Washington, DC, accessed November 21, 2017, http://www.embassyofindonesia.org/index.php/national-symbols/.

11. Adam Schwarz, A Nation in Waiting: Indonesia's Search for Stability, 2nd ed. (Boulder, CO: Westview, 1999), 10, 41.

12. Quoted in Bahar, Kusuma, and Hudawati, Risalah, 260-63, 299.

13. Ignatius Haryanto, Pembredelan Pers di Indonesia: Kasus Koran Indonesia Raya (Jakarta: LSPP, 1995), 41.

14. ICJ, Indonesia and the Rule of Law: Twenty Years of "New Order" Government (London: Pinter, 1991), 86.

15. Haryanto, Pembredelan Pers, 42.

16. Togi Simanjuntak, ed., Wartawan Terpasung: Intervensi Negara di Tubuh PWI (Jakarta: ISAI, 1998), 25-27.

17. Haryanto, Pembredelan Pers, 43-44.

18. The declaration occurred a few months before the government's official announcement of a state of emergency and martial law in March 1957.

19. Schwarz, Nation in Waiting, 16.

20. Robert Cribb and Colin Brown, Modern Indonesia: A History Since 1945 (London: Longman, 1995), 82-83.

21. Sukarno, "Saving the Republic of the Proclamation (1957)," in Indonesian Political Thinking: 1945-65, ed. Herbert Feith and Lance Castles (Ithaca, NY: Cornell University Press, 1970), 86.

22. Reeve, "Corporatist State"; Bourchier, "Totalitarianism and the 'National Personality."'

23. Simanjuntak, Wartawan Terpasung, 39, 34; Oey Hong Lee, Indonesian Government and Press during Guided Democracy, Hull Monographs on Southeast Asia 4 (Zug, Switzerland: Inter Documentation, 1971).

24. Lee, Indonesian Government.

25. Penetapan Presiden No. 6/1963 tentang Pembinaan Pers.

26. Simanjuntak, Wartawan Terpasung, 26, 53-61.

27. Quoted in Schwarz, Nation in Waiting, 6, 11.

28. Cribb and Brown, Modern Indonesia, 51.

29. Herbert Feith, The Decline of Constitutional Democracy in Indonesia (Ithaca, NY: Cornell University Press, 1962), 556-608.

30. For example, Daniel Lev has characterized the 1950-57 period of democracy in Indonesia as "much condemned but extraordinarily successful." Speech before the Indonesia Forum, Jakarta, November 19, 1998.

31. Schwarz, Nation in Waiting, 6, 42.

32. Ibid., 18; Cribb and Brown, Modern Indonesia, 83.

33. Quoted in Schwarz, Nation in Waiting, 19-20.

34. Ibid., 22.

35. David Hill, The Press in New Order Indonesia (Nedlands: University of Western Australia Press, 1994), 34.

36. Act No. 11/1966 on the Basic Provisions on the Press, as amended by Act No. 4/1967, in L. M. Gandhi, Undang-undang Pokok Pers: Proses Pembentukan dan Penjelasannya (Jakarta: Rajawali Pers, 1985), 4-36.

37. Hill, Press in New Order Indonesia, 37.

38. Schwarz, Nation in Waiting, 32.

39. Daniel Dhakidae, "The State, the Rise of Capital and the Fall of Political Journalism: Political Economy of the Indonesian News Industry" (Ph.D. diss., Cornell University, 1991), 179.

40. Peter McCawley, "Some Consequences of the Pertamina Crisis in Indonesia," Journal of Southeast Asian Studies 9, no. 1 (March 1978): 6.

41. Dhakidae, "The State, the Rise of Capital," 172-75.

42. Ibid., 168-89. 
43. John Bresnan, Managing Indonesia: The Modern Political Economy (New York: Columbia University Press, 1993), 172-75.

44. Ibid., 165.

45. Quoted in Dhakidae, "The State, the Rise of Capital," 183-84.

46. Ibid., 207-8.

47. Schwarz, Nation in Waiting, 28-31.

48. Ibid., 32.

49. ICJ, Indonesia and the Rule of Law, 104.

50. Quoted in Schwarz, Nation in Waiting, 32.

51. Haryanto, Pembredelan Pers, 138.

52. Dhakidae, "The State, the Rise of Capital," 214.

53. Bresnan, Managing Indonesia, 135-39.

54. Dhakidae, "The State, the Rise of Capital," 85.

55. Hill, Press in New Order Indonesia, 37.

56. Schwarz, Nation in Waiting, 33-35.

57. Bresnan, Managing Indonesia, 163.

58. Cribb and Brown, Modern Indonesia, 131.

59. A.S. Hikam, Politik Kewarganegaraan: Landasan Redemokratisasi di Indonesia (Jakarta: Pernerbit Erlangga, 1999), 76.

60. ICJ, Indonesia and the Rule of Law, 104.

61. Quoted in Dhakidae, "The State, the Rise of Capital," 177.

62. Ibid.

63. Ibid., 309, 310.

64. Hill, Press in New Order Indonesia, 39.

65. Dhakidae, "The State, the Rise of Capital," 317, 319.

66. Heri Akhmadi, Breaking the Chains of Oppression of the Indonesian People: Defense Statement at His Trial on Charges of Insulting the Head of State (Ithaca, NY: Southeast Asia Program, Cornell University, 1981), 78.

67. Quoted in Dhakidae, “The State, the Rise of Capital,” 323.

68. Ibid., 320-23.

69. Act No. 21/1982 on Amendments to Act No. 11/1966 on the Basic Provisions on the Press, as amended by Act No. 4/1967, in Bambang Sadono, Penyelesaian Delik Pers Secara Politis (Jakarta: Pustakan Sinar Harapan, 1993), appendix 6, 158-65.

70. Quoted in ICJ, Indonesia and the Rule of Law, 102.

71. Quoted in Todung Mulya Lubis, In Search of Human Rights: Legal-Political Dilemmas of Indonesia's New Order, 1966-1990 (Jakarta: Gramedia), 288.

72. Schwarz, Nation in Waiting, 39.

73. Keputusan Dewan Pers No.79/XIV/1974 tentang Pedoman Pembinaan Idiil Pers.

74. Quoted in Dhakidae, "The State, the Rise of Capital," 459.

75. Yasuo Hanazaki, Pers Terjebak (Jakarta: ISAI, 1998), 47-48.

76. Reinforcing this impression, the anthropologist Clifford Geertz stated, "With the Javanese, you don't see the violence coming until it happens. Once the politeness and deference and controlled demeanor collapse, then all hell will break loose." Quoted in Philip Shenon, "Of the Turmoil in Indonesia and Its Roots," NYT, May 9, 1998.

77. Dhakidae, "The State, the Rise of Capital," 168-88.

78. Quoted in Hanazaki, Pers Terjebak, 47-48.

79. "Somehow, at one time, the notion was born that politics is dirty." Pramoedya Ananta Toer, "Literature, Censorship and the State: How Dangerous Are Stories?," an essay written for acceptance of the 1995 Ramon Magsaysay Award for Journalism, Literature and Creative Communication, trans. Marianne Katoppo, published in Suara Independen, no. 04/I, September 1995.

80. ICJ, Indonesia and the Rule of Law, 111.

81. Susanto Pujomartono, "Pers Indonesia Pasca Soeharto," in Reformasi Media Massa, ed. Ery Sutrisno (Jakarta: AJI, 1998), 10.

82. Dhakidae, "The State, the Rise of Capital," 459.

83. Hanazaki, Pers Terjebak, 47-48.

84. Vatikiotis, Indonesian Politics under Suharto, 104.

85. Ketetapan Majelis Permusyawaratan Rakyat Republik Indonesia No.II/MPR/1978 tentang Pedoman Penghayatan dan Pengamalan Pancasila (P4) dan Penegasan Pancasila Dasar Negara. 
86. Cribb and Brown, Modern Indonesia, 136.

87. INDOC, Indonesian Workers and Their Right to Organize: March 1984 Update (Leiden: INDOC, 1984), 13-15.

88. Thomas Fuller, "Indonesia Acts to Reform Language," IHT, December 22, 1999.

89. Pietra Widiadi, "Politik Bahasa dalam Pemberitaan," paper presented at Workshop Wartawan Multikulturalisme, Hotel Fortuna, Surabaya, February 25-29, 1999.

90. In 1999, the Jakarta Post provided definitions for over six hundred acronyms in common use in Indonesia at the time. JP, May 4, 1999.

91. Hill, Press in New Order Indonesia, 47.

92. Hanazaki, Pers Terjebak, 82.

93. Lubis, In Search of Human Rights, 288.

94. The periods covered were January $9-14$ and March 14-18, 1995. The papers surveyed were Kompas, Suara Pembaruan, Media Indonesia, Jakarta Post, and Republika. Hanazaki, Pers Terjebak, 81.

95. For example, quoting an army commander on November 14, Kompas reported, "Disturbance in Dili Is Regretted and Will Be Examined until Complete." Quoting a government minister on November 16, the paper used the passive voice in the headline, "A Special Investigative Team Will Be Formed"; and again when quoting President Suharto on November 18, "Handling Is to Be Done with Care and Coordinated as Well as Possible." On November 16, a Kompas headline read, "Foreign Minister Ali Alatas: An Investigatory Team to Be formed in East Timor."

96. Kompas, November 14, 16, and 18, 1991.

97. Quoted in Pujomartono, "Pers Indonesia Pasca Soeharto," 11-12.

98. In making these remarks, the authors of this history were referring to the work of the sociologist Richard V. Ericson. Simanjuntak, Wartawan Terpasung, 96.

99. Jalaluddin Rakhmat, "Revolusi Komunikasi," in Mencuri Kejernihan dari Kerancuan: Kumpulan Transkrip Wawancara Perspektif Baru Bersama Wimar Witoelar (Jakarta: Gramedia Pustaka Utama, 1998), 401-9.

100. Quoted in Hill, Press in New Order Indonesia, 47.

101. Goenawan Mohamad, personal communication, Jakarta, August 23, 1996.

102. Damien Kingsbury, The Politics of Indonesia (Melbourne: Oxford University Press, 1998), 111.

103. Hill, Press in New Order Indonesia, 46-47.

104. Quoted ibid., 47.

105. Ibid., 35; Susumu Awanohara, "Jakarta's Journalists Engage in a Guerilla War against Tight Guidelines: The Media Freedom Fighters," FEER, March 1, 1984.

106. Simanjuntak, Wartawan Terpasung, 78-110.

107. Haryanto, Pembredelan Pers, 54, 55-56.

108. Quoted in Simanjuntak, Wartawan Terpasung, 86.

109. Ibid., 86-87.

110. For example, SK Menteri Penerangan RI No. 47/1975, based on recommendations from the National Press Council.

111. Simanjuntak, Wartawan Terpasung, 100.

112. Hill, Press in New Order Indonesia, 69. $115-16$.

113. Interview with Atmakusumah Astraatmadja, in Simanjuntak, Wartawan Terpasung,

114. Ibid., 100-101.

115. For theoretical analysis of the context of this legacy in the emergence and consolidation of an elite oligarchy in Indonesia, see Jeffrey A. Winters, Oligarchy (Cambridge: Cambridge University Press, 2011); Richard Robison and Vedi R. Hadiz, Reorganising Power in Indonesia: The Politics of Oligarchy in an Age of Markets (London: Routledge, 2004); Michele Ford and Thomas B. Pepinsky, eds., Beyond Oligarchy: Wealth, Power, and Contemporary Indonesian Politics (Ithaca, NY: Cornell University Press, 2014); Ross Tapsell, "The Political Economy of Digital Media," in Digital Indonesia: Connectivity and Divergence, ed. Ross Tapsell and Edwin Jurriëns, 56-74 (Singapore: ISEAS, 2017).

116. Andrew Nette, "Hunt for Suharto’s Wealth a Political, Legal Maze," IPS, October 28, 1998.

117. "Indonesian Govt: 159 Pertamina Partners Linked to Cronyism," DJ, October 9, 1998.

118. Dan Murphy, “Things Fall Apart,” FEER, May 13, 1999. 
119. "Indonesia Spells Out Steps Taken to Eradicate Suharto-Era Corruption," AFP, September 1, 1998.

120. "MPR Asked to Rule on Soeharto," JP, October 22, 1998.

121. Masyarakat Transparansi Indonesia, Penelitian Keputusan Presiden Yang Menyimpang 1993-1998: Laporan Akhir Tim Kerja Bidang Hukum (Jakarta: Masyarakat Transparansi Indonesia, 1999).

\section{Delegitimating Authoritarianism}

1. Tim Wartawan, Buku Putih "Tempo": Pembredelan Itu (Jakarta: Alumni Majalah TEMPO, 1994), 17-25.

2. Ayu Utami, "A Letter from a Reporter," in Banning 1994, ed. AJI (Jakarta: AJI, 1994), 9.

3. Marsillam Simanjuntak, "Unsur Hegelian dalam Pandangan Negara Integralistik" (MA diss., University of Indonesia, 1989).

4. Articulated more fully in his later book, Marsillam Simanjuntak, Pandangan Negara Integralistik (Jakarta: Grafiti Pers, 1994), 254.

5. David Bourchier, "Totalitarianism and the 'National Personality,"” in Imagining Indonesia: Cultural Politics \& Political Culture, ed. Jim Schiller and Barbara Martin-Schiller (Athens: Ohio University Center for International Studies, 1997), 221-22.

6. Marsillam Simanjuntak, "Bicaralah dan Nyatakan!," Tempo, September 15, 1993, 33, cited in Indonesian Politics and Society: A Reader, ed. David Bourchier and Vedi Hadiz (London: Routledge, 2014), 218.

7. Robert W. Hefner, Civil Islam: Muslims and Democratization in Indonesia (Princeton, NJ: Princeton University Press, 2011), 162.

8. Bourchier, "Totalitarianism and the 'National Personality," 227-28.

9. Goenawan Mohamad, Sidelines: Thought Pieces from "Tempo" Magazine, trans. Jennifer Lindsay (Jakarta: Lontar, 1994), 69.

10. Ibid., 9-10.

11. Ibid., $47-48$.

12. Ibid., $67-68$.

13. Ibid., 73.

14. Ibid., 75-76.

15. Goenawan Mohamad, Conversations with a Difference: Essays from "Tempo" Magazine, trans. Jennifer Lindsay (Jakarta: PT Tempo Inti, 2002), vii-viii.

16. Mohamad, Conversations with a Difference, vii.

17. Mohamad, Sidelines, 65.

18. Ibid., 47, 13.

19. Y. B. Mangunwijaya, "The Indonesia Raya Dream and Its Impact on the Concept of Democracy," in Democracy in Indonesia: 1950s and 1990s, ed. David Bourchier and John Legge, 56-74 (Clayton, Victoria: Monash Papers, 1994), quoted in Angela Romano, Politics and the Press in Indonesia: Understanding an Evolving Political Culture (New York: Routledge, 2003$), 2$.

20. Soeharto, Pikiran, Ucapan, dan Tindakan Saya: Otobiografi, Seperti Dipaparkan kepada G. Dwipayana dan Ramadhan K. H. (Jakarta: Citra Lamtoro Gung Persada, 1989), 549, translated by Stefan Eklöf in Power and Political Culture in Suharto's Indonesia (Copenhagen: NIAS Press, 2003), 113.

21. Mohamad, Sidelines, 75-76.

22. On Tempo's provocative role, see Janet Steele, "Representations of 'The Nation' in Tempo Magazine," Indonesia 76 (Oct. 2003): 143.

23. Philip Kitley, Television, Nation, and Culture in Indonesia (Athens: Ohio University Press, 2000), 245.

24. Ibid., 180-186; personal observations of TVRI's evening news program, Berita Nasional, three times weekly from June 15 to August 16, 1996.

25. Kitley, Television, Nation, and Culture, 18.

26. Ibid., 150, 169, 307.

27. Sumita Tobing, "Development Journalism in Indonesia: Content Analysis of Government Television News" (PhD diss., Ohio University, 1991), 4.

28. Kitley, Television, Nation, and Culture, 176.

29. Respectively, RCTI, TPI (Cipta Televisi Pendidikan Indonesia), Indosiar (Indosiar Visual Mandiri), ANteve (Cakrawala Andalas Televisi), and SCTV (Surya Citra Televisi). 
30. Kitley, Television, Nation, and Culture, 239.

31. Ibid., 262.

32. Krishna Sen, "Media Politics in Indonesia," Pacific Review 16, no. 4 (2003): 573-89.

33. Wimar Witoelar, "Prakata," in Perspektif Bersama Wimar Witoelar (Jakarta: Yayasan Obor Indonesia, 1995), xi.

34. Wimar Witoelar, interview with author, Jakarta, April 23, 1999.

35. Wimar Witoelar, "Bertanya, Mewakili Audience," in Mencuri Kejernihan dari Kerancuan: Suatu Eksperimen dalam Komunikasi (Jakarta: PT Gramedia Pustaka Utama and InterMatrix Bina Indonesia, 1998), 15.

36. Bernard M. Timberg, Talk: A History of the TV Talk Show (Austin: University of Texas Press, 2002), 164.

37. Witoelar, "Prakata," xii.

38. Witoelar, "Bertanya," 7-8.

39. Ibid., 10.

40. Edwin Jurriëns, From Monologue to Dialogue: Radio and Reform in Indonesia (Leiden: Brill, 2009), 52.

41. Witoelar, "Bertanya," 5; Witoelar, "Tidak Mencerdaskan Orang," in Mencuri Kejernihan dari Kerancuan, x; Witoelar, "Bertanya," 10. 611.

42. Wimar Witoelar, "Expresi Melalui Cerpen," in Perspektif Bersama Wimar Witoelar, 599-

43. Ibid.

44. Ibid.

45. Ibid.

46. Ibid.

47. Witoelar, "Tidak Mencerdaskan Orang," xxviii.

48. "Dari DëTIK ke Time," Panji Masyarakat, July 1-10, 1994.

49. "Stop the Press," Newsweek, July 4, 1994. The tabloid's circulation reached 450,000 after only fifteen months in press.

50. "Laporan Utama: Habibie dan Kapal Itu," Tempo, June 11, 1994.

51. Duncan McCargo, "Killing the Messenger: The 1994 Press Bannings and the Demise of Indonesia's New Order," Harvard International Journal of Press/Politics 4, no. 1 (Winter 1999): 37.

52. Wartawan, Buku Putih, 19.

53. Quoted in Ahmad Taufik, Semangat Sirnagalih: 20 Tahun Aliansi Jurnalis Independen (Jakarta: AJI, 1994), 50.

54. Wartawan, Buku Putih, 103. (SIUPP).

55. PP Menpen No.01/Per/Menpen/1984 tentang Surat Izin Usaha Penerbitan Pers

56. Wartawan, Buku Putih, 100-101.

57. Mahanizar, "Janganlah Mematikan Nafkah," in Mengapa Kami Menggugat, ed. Bambang Bujono, Putu Setia, and Toriq Hadad (Jakarta: Yayasan Alumni TEMPO, 1995), 44.

58. Rachlan Nashidik, "Change Comes from Resistance," in AJI, Banning 1994, 92.

59. Quoted in Wartawan, Buku Putih, 46.

60. Ibid., 48.

61. "Messages of Sympathy Flow in to the Closed Magazines," JP, June 23, 1994.

62. Wartawan, Buku Putih, 66-67.

63. Quoted ibid., 98. RCTI, however, did not air this interview.

64. Article 19, Muted Voices: Censorship and the Broadcast Media in Indonesia (London: Article 19, 1996), 10.

65. Quoted in Wartawan, Buku Putih, 109.

66. Arbi Sanit, "Pembredelan di Era Keterbukaan: Selamat Tinggal Tempo, Editor dan DëTIK," Panji Masyarakat, July 1-10, 1994.

67. Wartawan, Buku Putih, 34.

68. Utami, "Letter from a Reporter," 8.

69. Stanley [Yoseph Adi Prasetyo], "Shattering the Myth of the Press Industry," in AJI, Banning 1994, 18.

70. Goenawan Mohamad, "Pengantar," in Wartawan, Buku Putih, vii.

71. Ibid.

72. Wartawan, Buku Putih, 70-71. 
73. Quoted ibid., 86, 38, 45.

74. Onghokham, "The New Order Returns to Zero," in AJI, Banning 1994, 47.

75. Arief Budiman, "The Press's Fears, Our Fears," in AJI, Banning 1994, 26.

76. For an account of the first offer to "save" Tempo by Suharto's son-in-law, Prabowo Subianto, see Janet Steele, Wars Within: The Story of "Tempo," an Independent Magazine in Soeharto's Indonesia (Singapore: Equinox, 2005), 146.

77. David Hill, The Press in New Order Indonesia (Nedlands: University of Western Australia Press, 1994).

78. Wartawan, Buku Putih, 103-4.

79. Aristides Katoppo, interview with author, Jakarta, April 20, 1999; Wartawan, Buku Putih, 104.

80. Margot Cohen, "Journalistic License? Press Freedom May Have Received a Shot in the Arm—but the Shadow of Control Lingers," FEER, November 11, 1999; Steele, Wars Within, 146.

81. “Tempo's 'Successor' Must Have Editorial Independence," JP, July 18, 1994.

82. Stanley, "Shattering the Myth," 19.

83. Wartawan, Buku Putih, 22.

84. "Life Goes On, amid Bitterness for Former Tempo Staff," JP, June 18, 1995.

85. “PPP Suggests Dialog to End Media Ban Crisis," JP, July 4, 1994.

86. "21 Tahun Pembredelan Tempo: Memicu PHK, Pemerintah Panik," Tempo.co, June 21,

2015, https://nasional.tempo.co/read/676973/21-tahun-pembredelan-tempo-memicu-phkpemerintah-panik.

87. Quoted in Atmakusumah, foreword to Hill, Press in New Order Indonesia, n.p.

88. Santoso, Ayu Utami, and Tony Hasyim, "SIUPP Dibatalkan, SIUPP Diharapkan," Forum Keadilan, July 21, 1994.

89. Yasuo Hanazaki, "The Indonesian Press in an Era of Kerterbukaan: A Force for Democratisation?" (PhD diss., Monash University, 1996), 22. Berita.

90. Wartawan, Buku Putih, 130-31. The new magazine was first called Opini, then

91. Hill, Press in New Order Indonesia, 97. This short-lived publication was called Simponi.

92. Hanazaki, "Indonesian Press," 108.

93. "Statement of Indonesian Journalists," July 5, 1994, provided to the author by AJI officer Heru Hendratmoko and later cited in Taufik, Semangat Sirnagalih, 67-68.

94. Hendrik Dikson Sirait, Melawan Tirani Orde Baru (Jakarta: AJI, 1999), 73.

95. "They Won't Lie Down," Economist, September 17, 1994.

96. Quoted in Atmakusumah, foreword, n.p. Of those who met, 58 signed the declaration.

97. Wartawan, Buku Putih, 108.

98. Ibid.

99. Human Rights Watch/Asia, "Press Closures in Indonesia One Year Later," Human Rights Watch/Asia 7, no. 9 (July 1995), https://www.hrw.org/report/1995/07/01/press-closuresindonesia-one-year-later.

100. John McBeth, "Troublesome Types: Jakarta Tightens Screws on Local Journalists," FEER, April 6, 1995. Independen published twelve issues before being banned.

101 Article 19, Pengadilan Pers di Indonesia: Kasus Aji dan Pijar (London: International Center Against Censorship, 1995), 9-10.

102. Human Rights Watch/Asia, "Press Closures," 1-3.

103. Heru Hendratkmoko, personal communication, Jakarta, February 26, 1999.

104. Toriq Hadad and Bambang Bujono, "Pendahuluan: Tonggak Sejarah dari Pokok Halim," in Bujono, Setia, and Hadad, Mengapa, 9.

105. Ibid., 12-13.

106. Atmakusumah, foreword, n.p.

107. Statement by Nurhasyim Ilyas, in Bujono, Setia, and Hadad, Mengapa, 70.

108. Bambang Bujono, Putu Setia, and Toriq Hadad, "Dari Gugatan sampai Duplik," in Mengapa, 94, 98.

109. Ahmad Taufik, "Menegakkan Benteng Terakhir Demokrasi," in Bujono, Setia, and Hadad, Mengapa, 22.

110. Rully Kesuma, "Jangan Main Hompimpah," in Bujono, Setia, and Hadad, Mengapa, 48.

111. Ahmed Kurnia Soeriawidjaja, "Hanya Sebagian dari Perlawanan," in Bujono, Setia, and Hadad, Mengapa, 23. 
112. Hidayat Surya Gautama, "Rasa Sesak Karena Teraniaya," in Bujono, Setia, and Hadad, Mengapa, 39.

113. Ivan Haris, "Semut Aje Bales Ngegigit," in Bujono, Setia, and Hadad, Mengapa, 41-42.

114. Ibid., 14, 5.

115. “Court Rules in Tempo's Favor," JP, May 4, 1995

116. See Bujono, Setia, and Hadad, Mengapa, 259-60, for the testimony of Sjamsul Basri, a member of the Press Council who confirmed that the Ministry of Information did not consult the Press Council before canceling the license.

117. Mohamad, "Pengantar," 2-7.

118. Ibid.

119. John McBeth, "Up Tempo," FEER, May 18, 1995. 219-20.

120. Siam Alamsjah, "Respons Itu Masih Terbatas," in Bujono, Setia, and Hadad, Mengapa,

121. "Mengabulkan Kasasi Menpen," Kompas, June 14, 1996.

122. "Wawancara Box Forum Khusus dengan Goenawan Mohamad: Putusan Kasus Tempo," Kompas, June 13, 1996.

123. "Hakim Benyamin Decegah Ditampilkan di TV," Media Indonesia Minggu, May 21, 1995.

124. Human Rights Watch/Asia, "Press Closures," 2-3; "Poetry-Meeting Banned," TAPOL Bulletin 125, October 1994, 6-9; "Dasar Hukum Keharusan Izin Dipertanyakan," Kompas, September 10, 1994; "Yang Terpuruk di Perizinan," Media Indonesia Minggu, June 18, 1995.

125. Amnesty International, Indonesia: Arrests, Torture and Intimidation: The Government's Response to Its Critics, November 27, 1996, AI Index no. ASA 21/70/96, https://www.amnesty. org/download/Documents/168000/asa210701996en.pdf.

126. Anne Heaton, "Ordeal in Indonesia," TAPOL Bulletin 125, October 1994, 24.

127. Mohamad, "Pengantar," vii.

128. Online sources included Kabar dari Pijar (http://www.pijar.net/kdpnet/index.html), SiaR (http://apchr.murdoch.edu.au/minihub/siarlist/maillist.html),Xpos (ekspos@hotmail. com), and Tempo Interaktif (http://www.tempo.co.id). See also David T. Hill, "Media Alternatif," Forum Keadilan, September 23, 1996; and Gerry van Klinken, "Indonesia on the Net," Inside Indonesia 51 (July-September 1997), http://web.archive.org/web/20080722064139/http://www. insideindonesia.org/content/view/860/29.

129. Krishna Sen and David T. Hill, Media, Culture and Politics in Indonesia (London: Equinox, 2006), 98-100.

130. Later, Witoelar likened the shows to cockroaches, popping up as quickly as the government could squash them. Wimar Witoelar, interview with author, Jakarta, July 10, 2009.

131. Stanley, "Shattering the Myth," 21-22.

132. Wartawan, Buku Putih, 30.

133. See, for example, Aristides Katoppo, quoted in Wartawan, Buku Putih, 53.

134. Mochtar Pabottingi, "Limits of the New Order, Limits of the Nation," in AJI, Banning $1994,86$.

135. Onghokham, "New Order Returns," 47.

136. Julia Suryakusuma, "The Ironies of Openness," in AJI, Banning 1994, 45.

137. McCargo, "Killing the Messenger," 29.

138. Goenawan Mohamad, personal communication, Jakarta, August 23, 1996.

139. Vince Boudreau, "Currency Crisis and Fragmented Mobilization in New Order Indonesia," in Indonesia's Interregnum: A Torturous Transition to Democratic Development, ed. Eduardo C. Tadem (Quezon City: University of the Philippines, Center for Integrative and Development Studies, 2000), 103.

140. Heru Hendratmoko, personal communication, Jakarta, January 28, 1999; Nicholas Kristof, "Two Forces That Tug at Indonesia," NYT, May 22, 1998.

\section{SuHARTO'S FALL}

1. Edward Aspinall, Opposing Suharto: Compromise, Resistance, and Regime Change in Indonesia (Stanford, CA: Stanford University Press: 2005), 121.

2. US Department of State, Indonesia Report on Human Rights Practices for 1997 (Bureau of Democracy, Human Rights, and Labor, US Department of State, January 30, 1998), section 2, Respect for Civil Liberties, including (a) Freedom of Speech and Press. 
3. Ibid.

4. Human Rights Watch, "Torture, Disappearances, and Arrests of Indonesian Activists," press release, April 1, 1998.

5. Goenawan Mohamad, "Pengantar," in Buku Putih "Tempo": Pembredelan Itu (Jakarta: Alumni Majalah TEMPO, 1994), viii-ix.

6. Webb Keane, "Freedom and Blasphemy: On Indonesian Press Bans and Danish Cartoons," Public Culture 12, no. 1 (December 2009): 47-76.

7. Ahmad Taufik, "Menegakkan Benteng Terakhir Demokrasi," in Mengapa Kami Menggugat, ed. Bambang Bujono, Putu Setia, and Toriq Hadad (Jakarta: Yayasan Alumni TEMPO, 1995), 22; Ahmad Taufik, personal communication, Jakarta, March 9, 1999.

8. Ging Ginanjar, personal communication, Jakarta, August 31, 2010.

9. AJI, ed., Banning 1994 (Jakarta: AJI, 1994); Bujono, Setia, and Hadad, Mengapa.

10. Daniel Dhakidae, "The State, the Rise of Capital and the Fall of Political Journalism: Political Economy of the Indonesian News Industry" (Ph.D. diss., Cornell University, 1991), 62-63.

11. Wartawan, Buku Putih, 84-85.

12. Quoted in Bujono, Setia, and Hadad, Mengapa, 8.

13. For this second incarnation, however, AJI took the precaution of publishing the newsletter from Australia. Heru Hendratmoko, personal communication, Jakarta, February 9, 1999. The underground newsletters Xpos and Bergerak also appeared in hard copy and online. Other organizations that put out critical newsletters included Pijar, whose bulletin Kabar Dari Pijar provoked office raids and arrests in 1995. Angela Romano, "The Open Wound: Keterbukaan and Press Freedom in Indonesia," Australian Journal of International Affairs 50, no. 2 (July 1996): 157-69. See also David T. Hill, "Media Alternatif," Forum Keadilan, September 23, 1996.

14. Andreas Harsono, "Indonesia: From Mainstream to Alternative Media," First Monday 1, no. 3 (September 1996), http://ojphi.org/ojs/index.php/fm/article/view/480/401.

15. Romano, "Open Wound."

16. Harsono, "Indonesia."

17. Marcus W. Brauchli, "Magazine Long Critical of Suharto Finds Itself Looking for a New Role," WSJ, June 3, 1998.

18. Quoted in Seth Mydans, "Activists Thrust Agendas into Post-Suharto Void," NYT, June 28, 1999.

19. Janet Steele, Wars Within: The Story of "Tempo," an Independent Magazine in Soeharto's Indonesia (Singapore: Equinox, 2005), 259-68.

20. Quoted ibid., 268.

21. Andrew Nette, "Hunt for Suharto's Wealth a Political, Legal Maze," IPS, October 28, 1998.

22. George J. Aditjondro, "Chopping the Global Tentacles of the Suharto Oligarchy," keynote address at the conference "Towards Democracy in Indonesia: Seize New Zealand Suharto Assets," Auckland University, March 23, 2000.

23. Masyarakat Transparansi Indonesia, Penelitian Keputusan Presiden Yang Menyimpang 19931998: Laporan Akhir Tim Kerja Bidang Hukum (Jakarta: Masyarakat Transparansi Indonesia, 1999).

24. "Indonesia's State Oil Firm 'Lost 6.1 Billion Dollars to Inefficiency,"” AFP, July 14, 1999.

25. “Suharto Family “Has US\$15b Fortune,” ST, May 17, 1999.

26. "Indonesian Govt: 159 Pertamina Partners Linked to Cronyism,” DJ, October 9, 1998.

27. Dan Murphy, "Things Fall Apart," FEER, May 13, 1999.

28. George J. Aditjondro, Dari Soeharto ke Habibie: Guru Kencing Berdiri, Murid Kencing Berlari: Kedua Puncak Korupsi, Kolusi, dan Nepotisme Rezim Order Baru (Jakarta: Pijar Indonesia \& Masyarakat Indonesia untuk Kemanusiaan, 1998). 1999.

29. John Colmey and David Liebhold, "Suharto, Inc.: All in the Family," Time Asia, May 24,

30. Louise Williams, "Poor Little Rich Kids," SMH, October 24, 1998.

31. "More Land Holdings of the Former First Family Have Been Uncovered," ST, December 2, 1998.

32. Grainne McCarthy, "Asia Econ Growth Doesn't Merit Rate Hikes-Deutsche Bank," WSJ, March 23, 2000.

33. Michael Spencer, quoted ibid.

34. "The Rot in Indonesia," editorial, NYT, March 6, 1998. 
35. Heru Hendratmoko, "Keroposnya Sebuah Mitos: Pers Indonesia," in Masyarakat dan Negara, Kado untuk Prof Soetandyo Wignjosoebroto MPA, ed. Basis Susulio, 161-70 (Surabaya: Airlangga University Press, 1997).

36. A reading of the media coverage for the last three months of 1997 indicates that Englishlanguage newspapers, such as the Jakarta Post and the Indonesian Observer, carried the most critical coverage. 1998.

37. Seth Mydans, "Indonesian Students Keep Protests Well Within the Pale," NYT, March 29,

38. Kristof, “'People Power' Unrest of Indonesian Campuses,” NYT, April 29, 1998.

39. Quoted in Mydans, "Indonesian Students."

40. Allan Nairn, "Indonesia's 'Disappeared,” TN, June 8, 1998.

41. John Roosa, "Reappearance of the Disappeared," email report, April 23, 1998.

42. Allan Nairn, "Indonesia's Killers," TN, March 30, 1998.

43. Roosa, "Reappearance."

44. Aspinall, Opposing Suharto, 203.

45. Quoted in Kristof, "People Power."

46. Nairn, "Indonesia's Killers."

47. Quoted in Mydans, "Indonesian Students."

48. Roosa, "Reappearance."

49. Harsono, "Indonesia."

50. "Presiden di Tengah Krisis," DER, March 7, 1998.

51. Budiman S. Hartoyo, interview with author, Jakarta, March 31, 1999.

52. Quoted in Lukas Luwarso and Dadang Rhs, "AJI Condemn Soeharto Statement," press release from AJI, April 18, 1998, https://peace.home.xs4all.nl/pubeng/pdm/ajics.html.

53. The original Indonesian reads, "Harga kejujuran lebih mahal dari harga sembako." Reuters photo, published in Seth Mydans, "At Pivotal Time, Suharto Gets 7th Term,"NYT, March 11, 1998.

54. Nairn, "Indonesia's 'Disappeared."”

55. Roosa, "Reappearance."

56. Gerry van Klinken, "Indonesia on the Net," Inside Indonesia 51 (July-September 1997), http://web.archive.org/web/20080722064139/http://www.insideindonesia.org/content/ view/860/29.

57. "Chronology of Indonesian Crisis," Reuters, October 18, 1999.

58. Kukuh Sanyoto, interview with author, tape recording, Jakarta, May 19, 1999.

59. Kukuh Sanyoto, "Indonesian Television and the Dynamics of Transition," in Media Fortunes, Changing Times: ASEAN States in Transition, ed. Russell H. K. Heng (Singapore: Institute for Southeast Asian Studies, 2002), 95.

60. Quoted in Mark Landler, "Riots Break Out in Jakarta after Shooting of Students," NYT, May 14, 1998.

61. Ibid.

62. Richard Stevenson, " 8 World Leaders Urge Suharto Show Restraint in Handling Indonesian Turmoil," NYT, May 16, 1998.

63. Philip Shenon, "U.S. to Appeal to Indonesia Military to Stop Crackdown," NYT, April 14, 1998.

64. Mark Landler, "Indonesian Capital Engulfed by Rioting," NYT, May 15, 1998.

65. Tim Gabungan Pencari Fakta, Laporan Akhir Tim Gabungan Pencari Fakta Peristiwa Tanggal 13-15 Mei 1998 (Jakarta: Tim Gabungan Pencari Fakta, October 23, 1998).

66. An oft-cited and, as it turns out, misleading statistic in circulation at the time was that Chinese Indonesians, though only 3 percent of the population, controlled 70 percent of the economy. See George Aditjondro, "The Myth of Chinese Dominance in Indonesia," JP, August 14, 1998.

67. Mark Landler, "The Target of Violence in a Time of Wrath," NYT, May 15, 1998.

68. See, for example, Martin R. Jenkins, "Nation Basks in Self-Deception," JP, May 13, 2000; Tim Gabungan Pencari Fakta, Laporan Akhir.

69. Wimar Witoelar, "The Role of the Media and the Recent Changes in Indonesian Politics," University of Wisconsin-Madison, Center for Southeast Asian Studies Friday Forum Lecture Series, October 22, 1999.

70. Ariel Heryanto, "Flaws of Riot Media Coverage," JP, July 15, 1998. 
71. Landler, "Riots Break Out."

72. Quoted in Seth Mydans, "2 Top Figures in Indonesia Clash on Seeking Suharto's Resignation," NYT, May 19, 1998.

73. Dewi Loveard, "Diary: A Depressing Journey through Central Java," Asiaweek, September 25, 1998.

74. Mydans, "2 Top Figures."

75. Mark Landler, "In Indonesia, the Grab for Power May Hinge on the Rivalry of 2 Generals," NYT, May 18, 1998. 1998.

76. Nicholas Kristof, "High Stakes for Suharto: No Graceful Way Out?," NYT, May 19,

77. Mydans, "2 Top Figures."

78. Seth Mydans, "In a Suharto Fief, 'Hang Suharto!’” NYT, May 19, 1998.

79. Kristof, "High Stakes."

80. Nicholas Kristof, “A Toothless Tiger? Army's Will Is Doubted,” NYT, May 21, 1998.

81. Mydans, "2 Top Figures."

82. Nicholas Kristof, "Filling Power Vacuum: Will Army Rule?" NYT, May 21, 1998. 1998.

83. Mark Landler, "Joyfully, Indonesian Students Thumb Noses at Authority," NYT, May 20, 1998

84. Seth Mydans, "Army Out in Force to Halt Protests Aimed at Suharto," NYT, May 20,

85. Seth Mydans, "Suharto Steps Down after 32 Years in Power," NYT, May 21, 1998.

86. Philip Shenon, "U.S. Steps Up Pressure on Suharto," NYT, May 21, 1998.

87. Seth Mydans, "Top General Strengthens His Grasp on Power," NYT, May 23, 1998.

88. Mydans, "Suharto Steps Down."

89. Endy M. Bayuni, "Indonesia's Journalists Will Preserve Their New Freedom," WSJ, August 12, 1998.

90. Aspinall, Opposing Suharto, 254.

91. Bayuni, "Indonesia's Journalists."

92. Aspinall, Opposing Suharto, 252.

93. For further analysis, see Duncan McCargo, "Killing the Messenger: The 1994 Press Bannings and the Demise of Indonesia's New Order," Harvard International Journal of Press/Politics 4, no. 1 (1999): 29-47.

94. Aspinall, Opposing Suharto, 129.

\section{REFORMASI}

1. Jeffrey Winters, "Leadership in Indonesian Politics," keynote address at the conference "Indonesia Next," Jakarta, May 2001. 4, 1998.

2. Quoted in Tim Healy and Jose Manuel Tesoro, "Judging Habibie," Asiaweek, September 1998

3. "Two out of Three Indonesians Will Fall below Poverty Line: ILO," AFP, August 31,

4. David Lamb, “Clouds Haven't Lifted in Post-Suharto Indonesia," LAT, October 1, 1998.

5. Louise Williams, "Rubber Bullets Warning as Prices Rocket," SMH, September 1, 1998.

6. "Indonesia on the Brink," Singapore Business Times, September 11, 1998; Dewi Loveard, "Indonesia's Mean Streets," Asiaweek, September 25, 1998; Lamb, "Clouds Haven’t Lifted."

7. Lamb, "Clouds Haven't Lifted."

8. Neil Weinberg, "What Devaluation Hath Wrought," Forbes, October 5, 1998.

9. Williams, "Poor Little Rich Kids"; David Jenkins, "Habibie's Challenge," SMH, October 26, 1998; Weinberg, "What Devaluation Hath Wrought."

10. Quoted in Jenkins, "Habibie's Challenge."

11. "Bid to License Journalists Rapped," ST, July 17, 1998.

12. "Press Gets New Freedom," JP, editorial, July 31, 1999.

13. Seth Mydans, "Suharto Steps Down after 32 Years in Power," NYT, May 21, 1998.

14. Gerry van Klinken, "Round Two: Suharto’s Comeback?," Inside Indonesia, June 22, 1998; Jeremy Wagstaff, "Habibie's Speech Fails to Sway Skeptics: Ability to Deliver 'Civil Society' in Doubt," WSJ, August 17, 1998; Seth Mydans, "New Leader Vows Early Elections for Indonesians," NYT, May 26, 1998. 
15. Marcus W. Brauchli, "Magazine Long Critical of Suharto Finds Itself Looking for a New Role,” WSJ, June 3, 1998.

16. Eyewitnesses claimed to have seen Yosfiah pull the trigger. See "UN Links Ex-Jakarta Minister to Timor Murders-Paper," Reuters, February 3, 2001.

17. Mohammad Yunus Yosfiah, interview with author, Jakarta, June 10, 1999; Mohammad Yunus Yosfiah, Forum Aspirasi, TVRI, March 15, 1999, quoting Thomas Jefferson, letter to Colonel Edward Carrington, January 16, 1787.

18. Peraturan Menteri Penerangan Republik Indonesia No. 01/PER/MENPEN/1998 tentang Ketentuan-Ketentuan Surat Izin Usaha Penerbitan Pers. The form required a signature from a Ministry of Information official (usually the director general of press, printing and graphics), but from my observations at the ministry in 1999, approval appeared to be automatic. If the office was not busy, one could complete the entire process in a matter of minutes. By contrast, in the early 1990s, Jakarta-Jakarta spent close to Rp300 million (around \$130,000) just to secure a new SIUPP when the ministry forced it to become an entertainment magazine after it published a controversial report on the 1991 army-perpetrated massacre in Dili, East Timor. Yosep Adi Prasetnyo, "Kepemilikan Modal di Media Massa dan Implikasinya bagi Kebebasan Pers: Mencari Format Organisasi Kewartawan yang Ideal, Notelensi Diskusi II," in Reformasi Media Massa, ed. Ery Sutrisno (Jakarta: AJI, 1998), 112.

19. Surat Keputusan Menteri Penerangan Republik Indonesia No. 133/SK/MENPEN/1998.

20. Surat Keputusan Menteri Penerangan Republik Indonesia No. 134/SK/MENPEN/1998.

21. S. Leo Batubara, speech delivered at "Demokrasi, Kebebasan Pers, dan Hukum Seminar," Universitas Atma Jaya, Jakarta, April 7, 1999.

22. This stipulation applied to publications that had ceased operations for six months or more. R. H. Siregar, speech delivered at "Demokrasi, Kebebasan Pers, dan Hukum Seminar," Universitas Atma Jaya, Jakarta, April 7, 1999.

23. AJI, "Aturan Baru Menteri Penerangan: Reformasi Setengah Hati," AJI statement, apakabar@clark.net, June 6, 1998. The relevant regulations were Permenpen No. 1/1998, SK Menpen No. 133/1998, and SK Menpen No. 134/1998.

24. A total of 289 licenses were granted under Suharto. Jose Manuel Tesoro, "Indonesia: Learning the Ropes of Press Freedom," UNESCO Courier 2 (February 2000): 43-45; Sheila Coronel, "Media-Indonesia: After the Euphoria, Press under Attack," IPS, June 2, 2000.

25. The changing tone and topics of Indonesia's print coverage are evident in appendixes 1,2 , and 3, which comprise sample headlines from Jakarta's leading news magazines and tabloids in 1985, 1990, and 1999.

26. Reported in Seth Mydans, "With Suharto Empire under Fire, 2 Kinsmen Are Ousted from Jobs," NYT, May 30, 1998; Seth Mydans, "Reeling Indonesia Gets Fiscal Break," NYT, May 31, 1998.

27. Mydans, "New Leader Vows."

28. "Pelanggaran HAM di Aceh," TPI, August 22, 1998; "Pelucutan Senjata di Tim-Tim," TPI, March 14, 1999.

29. David T. Hill, The Press in New Order Indonesia (Nedlands: University of Western Australia Press, 1994), 88.

30. A. Lin Neumann, "Radio Reformasi: Climate of Political Openness Frees Jakarta's Airwaves," FEER, September 17, 1998.

31. “'Talk-Show' Menjadi Unggulan TV Swasta,” Kompas, June 25, 1998.

32. A good example was a debate on April 1, 1999, between Sri Bingtang Pamungkas, a former political prisoner and chairman of the Indonesian Democratic Union Party, and Ryaas Rasyid, the outspoken director general of the Ministry of Home Affairs. Throughout the discussion, Rasyid and Pamungkas got so caught up in their debate they began interrupting each other and generally ignored the host's attempts to moderate. Pro dan Kontra, TPI, April 1, 1999.

33. Melinda Quintos de Jesus, “'Coming of Age’: Media and Society,” Manila Times, November 12, 1998.

34. For example, in his State of the Nation address on August 15, 1999. See Kafil Yamin, "Habibie's Piecemeal Approach Riles Critics," IPS, August 24, 1998; "Indonesian Student Protests Should Be Allowed: Minister," AFP, October 25, 1998; "Indonesian Press Appeals to Govt Officials for Openness," AP, October 27, 1998.

35. "Bid to License Journalists"; Yamin, "Habibie's Piecemeal Approach." 

1998.

36. "Indonesia: Military Intervention in Labour Disputes," Asian Food Worker, September

37. Hikmahanto Juwana, "Special Report Assessing Indonesia's Human Rights Practice in the Post-Soeharto Era: 1998-2003," Singapore Journal of International \& Comparative Law 7 (2003): 646.

38. Jenny Grant, "Actress Summonsed over 'Insult,"” SCMP, September 19, 1998; Ratna Sarumpaet, personal communication, Jakarta, March 4, 1999.

39. Suzanne Charl, "Indonesia's Students Traditionally Speak Out for the Voiceless," TN, October 5, 1998.

40. That which does not offend, she points out, requires no protection. Jean Goodwin, lecture, "Communication Studies C30: Contemporary Problems in Freedom of Speech," Northwestern University, Evanston, IL, January 16, 1998. 2008.

41. Quoted in Subhatra Bhumiprabhas, "Media: Pressing for Their Freedom," TN, May 22,

42. "Pemerkosaan di Bulan Mei 1998: Cerita \& Fakta," Tempo, October 6-12, 1998.

43. "Jejak Cendana di Banyuwangi." Witnesses described the perpetrators as groups of men, dressed in black coats and masked in the style of Japanese ninja assassins, who displayed unusual physical prowess and then vanished into thin air. Yusi A. Pareanom, Ardi Bramantyo, Andari Karina, and Zed Abidien, "Pembunuhan Berantai di Bumi Osing," Tempo, October 19, 1998; "Kisah Mateha yang Tak Mati-Mati," Tajuk, October 15, 1998. See also "Murders May Be Organized: Kontras," JP, October 10, 1998; Nicholas D. Kristoff, "Fears of Sorcerers Spur Killings in Java," NYT, October 20, 1998; Kees van Dijk, "Mysterious Killings," in A Country in Despair: Indonesia between 1997 and 2000 (Leiden: KITLV Press, 2001), 359-77; S. Saiful Rahim, Merah Darah Santet di Banyuwangi (Jakarta: Metro Pos, 1998). The earliest victims in July 1998 had been identified as "sorcerers" (dukun santet), killed in what many assumed to be local acts of vengeance related to the alleged practice of black magic. In August, however, the body count jumped to nearly fifty; it doubled again in September, when the profile of victims suddenly expanded to include Muslim clerics, many of them members of Nahdlatul Ulama. By midDecember, the number had reached 248 , featuring ever more grisly displays, including chopped up body parts thrown into nearby mosques or hung from trees in bags. Jason Brown, "The Banyuwangi Murders: Why Did over a Hundred Black Magic Practitioners Die in East Java Late in 1998?" Inside Indonesia, April-June 2000; "Mystery Murder Spree Takes New Twist in Indonesia," Reuters, October 2, 1998; Derwin Pereira, "Special Report: Java's Ninja Terror," ST, October 30, 1998.

44. Kafil Yamin, “Killings of Islamic Teachers Spread Fear," IPS, November 2, 1998.

45. Bhimo Widadi, Augustono, and Dwi Ani, "Kuantar ke Gerbang Kehancuran," DëTAK, November 3-9, 1998.

46. See Yamin, "Killings of Islamic Teachers."

47. SiaR, for example, reported that their sources questioned the suspicious circumstances of the killings. One source said the killers were clearly professionals. "Before acting, they cut the electricity throughout the village. Who [else] could do such a thing?" "Satuan ABRI Diduga di Belakang Pembantaian Banyuwangi," SiaR email list, October 7, 1998, http://apchr.mur doch.edu.au/minihub/siarlist. See also "Ninja Operation, Intelligence Operation," Gatra, October 31, 1998; "Kasus Dukun Santet di Banyuwangi: Pelaku Pembantaian Dibayar Rp250.000," SP, October 7, 1998; "Security Involvement in Anti-religious 'Ninja' Killings," Kedaulatan Rakyat October 30, 1998. Findings of investigating teams from NU, Partai Keadilan, and Kontras also suggested military or government involvement. Assailants, for instance, were seen arriving in vehicles bearing nonlocal license plates, using maps of the area that allowed them easy escape, and assisted by electricity blackouts that preceded several attacks. "Murders May Be Organized." Partai Keadilan also found it suspicious that police, who were normally slow to respond, would appear, unsummoned, within minutes when locals captured a suspected "ninja." "Conclusions of the Fact-Finding Team of Partai Keadilan of East Java," cited in S. Saiful Rahim, Merah Darah Santet di Banyuwangi (Jakarta: Metro Pos, 1998).

48. "Jejak Cendana di Banyuwangi: Pengakuan desertir Kopassus," November 3-9, 1998; "Pengakuan Desertir Kopassus: Target Kelompok Cikarang Gagalkan Kongres PDI," DëTAK, November 3-9, 1998.

49. "Pengakuan Desertir Kopassus."

50. "Nggak Ada Desertir Kopassus," interview with Major General Syamsul Ma'arif (Kapuspen ABRI), DëTAK, November 3-9, 1998. 
51. See John Sidel, Riots, Pogroms, Jihad: Religious Violence in Indonesia (Ithaca, NY: Cornell University Press, 2006), 138-39.

52. Tim Gabungan Pencari Fakta, "Laporan Akhir Tim Gabungan Pencari Fakta Peristiwa Tanggal 13-15 Mei 1998," executive summary, Jakarta, October 23, 1998 (released to the public on November 3, 1998).

53. See George Junus Aditjondro, "Guns, Pamphlets and Handie-Talkies: How the Military Exploited Local Ethno-religious Tensions in Maluku to Preserve Their Political and Economic Privileges," in Violence in Indonesia, ed. Ingrid Wessel and Georgia Wimhoefer, 228-53 (Hamburg: Abera, 2001).

54. Charl, "Indonesia's Students."

55. Chapter VI, Ketetapan Majelis Permusyawaratan Rakyat Republik Indonesia, No. XVII/ MPR/1998 Tentang Hak Asasi Manusia, Bab 5, Pasal 19.

56. Video montage of the 1998 parliamentary special session, Anteve Gema Senayan, ANteve, November 13, 1998.

57. The main stations providing live coverage were Ramako-FM, Trijaya-FM, RRI's ProduaFM, Sonora, and Elshinta. For a detailed report on the role of radio in 1998 in covering these events, see "Mendengar Radio Dengan Back Sound Desingan Peluru," Republika, November 24, 1998.

58. Lukas Luwarso, "Protes Atas Kekerasan Aparat terhadap Wartawan," AJI statement, Jakarta, November 13, 1998.

59. Ibid. ANteve also reported this complaint. Gema Senayan, ANteve, November 11, 1998.

60. Cakrawala, ANteve, November 12, 1998.

61 . Figures on the number killed vary in reports on the incident, even within the same sources, numbering anywhere from five to nineteen. In a later and more definitive report, the Jakarta Post confirmed sixteen deaths, including six university students, but noted that the head of the nongovernmental organization Kontras put the number at nineteen, adding that at least six students remained missing. "Parents of Dead Students Seek Justice," JP, December 2, 1998.

62. 7 p.m. report, TVRI, November 14, 1998.

63. For a more detailed analysis, see chapter 5; Wimar Witoelar, "Black Friday Due to Impudence," JP, November 21, 1998.

64. Ketetapan Majelis Permusyawaratan Rakyat Republik Indonesia, No. XVII/MPR/1998 Tentang Hak Asasi Manusia, Bab 5, Pasal 19.

65. This impression is based on conversations with journalists and editors in November and December of 1998. The fragility of the press's position was also a main theme of a discussion on media freedom led by Atmakusumah Astraatmadja (then director of the Dr. Soetomo Press Institute) and held in Jakarta on November 16. See "Expert Warns against Moves to Gag Freedom of the Media," JP, November 19, 1998.

66. Tajuk faced a suit from the Greater Jakarta Regional Military Command (Kodam Jaya) over a report published on September 3, 1998, "Saksi-saksi Setelah 100 Hari," that implicated the regiment, and Major General Sjafrie Sjamsuddin in particular, in orchestrating the May 1998 riots. See "Buruk Muka, Pers Digugat," Xpos, September 12-18, 1998, http://apchr.murdoch. edu.au/minihub/xp. Similarly, the governor of South Sulawesi, Zainal Basri Palaguna, charged $D \mathcal{E} R$ with libel after the magazine published a report in June 1998 exposing his involvement in corruption. The papers DëTAK and Merdeka also found themselves in trouble with the minister of internal affairs after reporting on his role in a 1996 PDI congress that led to the party's split. $D \ddot{T} T A K$ had to fend off a lawsuit by a former Kopassus commander, Colonel Chairawan K. Nusyirwan, who had been discharged over the magazine's reports on the Banyuwangi murder sprees. Ezki Suyanto, interview with author, Jakarta, March 10, 1999.

67. Heru Hendratmoko, email communication, Jakarta, February 9, 1999.

68. Ibid.

69. The group also began drafting a broadcasting law to go with the print media law, and later changed its name to the Indonesian Press and Broadcasting Society (Masyarakat Pers dan Penyiaran Indonesia).

70. Mohammad Yunus Yosfiah on "Dialog Khusus," hosted by Yunuk Parwati, TVRI, September 29, 1998.

71. "Kasus Panji Masyarakat Batu Ujian untuk Kebebasan Pers," editorial, Kompas, February 24, 1999; "Sebuah Ujian untuk Integritas Wartawan," Berita Buana, February 20, 1999; "Wakil Pemimpin Umum Panji Masyarakat Beri Kesaksian,” Republika, February 20, 1999. 
72. The exact number of media outlets that obtained copies of the original cassette is difficult to confirm since most later stories on its contents simply referenced the transcript from Panji's report. (Panji Masyarakat received its copy of the cassette in mid-February. Uni Zulfiani Lubis, interview with author, Jakarta, April 30, 1999.) However, insiders at Kompas, Tempo, and DëTAK acknowledged privately that their publications had each received a copy. The small tabloid Berita Keadilan also at least had access to a copy, used for its January report on the conversation (which went largely unnoticed), cited below. Eventually, several television and radio stations aired the conversation using their own copies.

73. The passage in Indonesian reads, “. . . kalau cuma dua jam juga nanti orang, wah, sandiwara apa lagi nih." Quoted in "Beredarnya Rekaman Ghalib-Habibie: Halo, Ghalib dan Habibie di Sini," Panji Masyarakat, February 24, 1999. The Indonesian word sandiwara could also be translated as "farce," but more generally refers to any staged drama or play-acting.

74. Translated from the transcript in "Beredarnya Rekaman Ghalib-Habibie."

75. "The Tale from the Tape," JP, February 20, 1999; "Sulit Hindari Kesan Intervensi Kekuasaan atas Kasus Hukum," Kompas, February 22, 1999. See also the comments of the Indonesian Legal Aid and Human Rights Association lawyer Hendardi [one name], in "Isi Rekaman Mengejutkan," SP, February 20, 1999. 1999.

76. “Percakapan Rahasia Habibie-Ghalib Soal Soeharto," Berita Keadilan, January 6-12,

77. "Beredarnya Rekaman Ghalib-Habibie."

78. "Isi Rekaman Mengejutkan"; "Berharap Selamat dari Kata 'Mirip,"” Berlian, February 22-28, 1999.

79. In Jakarta and Surabaya, over a dozen street hawkers and newsstand owners I spoke with in late March said that after the story, most increased their orders of the magazine. Even with this added stock, in the first weeks after the story, some said they would still run out of copies by midmorning.

80. "Rekaman Diteliti, Asli atau Rekayasa," SP, February 19, 1999; Trimoelja D. Soerjadi, interview with author, Surabaya, February 28, 1999.

81. "ABRI to Probe Phone Tap Scandal," JP, February 20, 1999.

82. Uni Zulfiani Lubis, interview with author, Jakarta, April 30, 1999.

83. Ibid.

84. An exception was Sonora-FM, whose chief editor was one of the fourteen summoned even though the station had not aired the cassette. This mistake was a source of amusement to the staff at Ramako-FM, who had broadcast the cassette but were not called in. Deddy Rachmat, personal communication, Jakarta, March 17, 1999. 1999.

85. ANteve news director Azkarmin Zaini, quoted in "Polisi Bingung," Surya, February 24,

86. Uni Zulfiani Lubis, interview with author, Jakarta, April 30, 1999.

87. Ibid. 2001.

88. Ridlo Aryanto, "Roy Suryo, Pioneer in Multimedia Documentation," JP, February 4,

89. "Bergaya Mafia," DëTAK, March 23-29, 1999. Suryo mentioned this concern shortly after arriving in Jakarta. Roy Suryo, personal communication, Jakarta, March 17, 1999. BIA's involvement in the disappearances, as well as in the torture during interrogation later reported by those who escaped, was well-documented in investigations by both nongovernmental organizations and the US State Department. See Allan Nairn, “Indonesia's 'Disappeared,"” TN, June 8, 1998.

90. Roy Suryo, personal communication, Jakarta, March 17, 1999. Regardless, the story of Suryo's encounter with BIA further fueled rumors that military intelligence was behind the leak. Deddy Rachmat, personal communication, Jakarta, March 17, 1999.

91. "Penyadapan," Jurnal 30, Ramako-FM, March 17, 1999. 1999.

92. Panji Masyarakat advertising department, personal communication, Jakarta, April 30,

93. M.S. Zulkarnaen, interview with author, Jakarta, April 30, 1999.

94. Budiman S. Hartoyo, interview with author, Jakarta, March 31, 1999.

95. Ezki Suyanto, interview with author, Jakarta, March 10, 1999.

96. Uni Zulfiani Lubis, interview with author, Jakarta, April 30, 1999.

97. Ezki Suyanto, interview with author, Jakarta, March 10, 1999. 
98. Ibid.

99. Print coverage of the case moved away from the contents of the recorded conversation almost immediately. In their initial reports, Jakarta's main dailies focused overwhelmingly on national security questions and officials' search for the source of the wiretap. See, for example, "Presiden Soal Pembicaraan dengan Jaksa Agung: Selidiki Yang Bocorkan," Kompas, February 19, 1999; "Skandal Penyadapan Telpon: Ada Orang Berbahaya Dekat Habibie," Berita Buana, February 19, 1999; "Teroris Hadir di Mana Saja," Lensa, February 27-March 5, 1999; "Kemungkinan Orang Dalam Terlibat," MI, February 20, 1999; "ABRI to Probe Phone Tap Scandal and Officials Say Palace Phone System Safe," JP, February 20, 1999; "DPR Minta Pangab Beri Penjelasan: 'Itu Kejahatan Spionase Terencana,"” Republika, February 20, 1999; "Kasum: Mungkin ABRI Lakukan Konspirasi," Republika, February 20, 1999. Several broadcasters, beginning with ANteve, did keep attention on Habibie and Ghalib's alleged conversation by airing the actual recording, allowing audiences to judge the tape's authenticity for themselves, and later print coverage in this vein included calls for impeachment proceedings and demands for Ghalib's resignation. See, for example, "Mathori: Habibie Harus Di-Impeach, PKB Desak Presiden Copot Jaksa Agung," Jawa Pos, February 25, 1999; "Habibie Harus Ubah Kebijakan," Kompas, February 25, 1999; "FPP Cari Dukungan Impeachment," Jawa Pos, February 27, 1999. Ultimately, however, the shift in attention to security served Habibie by taking the focus off the "charade" investigation of Suharto, allowing defenders to rail instead against the unknown traitor who was trying to "bring down the government." "'Itu Kejahatan Espionase Terencana," Republika, February 20, 1999.

100. For more on this consensus, see Mary E. McCoy, "The Media in Democratic Transitions: Institutionalizing Uncertainty in Post-Suharto Indonesia" (PhD diss., Northwestern University, 2005). 1999.

101. Tarman Azzam, quoted in "PWI Siap Bantu Majalah Panji Masyarakat," SP, February 22,

102. Act No. 11/1966 on the Basic Provisions on the Press, as amended by Act No. 4/1967 and later amended by Act No. 21/1982.

103. Specifically, the elucidation of the amendment states, "the Right of Refusal . . . does not apply in matters involving especially the order and security of the State." Elucidation on Chapter V, Article 15, sections (6) and (7) of Act No. 21 of 1982, amending Act No. 11/1966 on the Basic Provisions on the Press, as amended by Act No. 4/1967.

104. Ketetapan Majelis Permusyawaratan Rakyat Republik Indonesia, No. XVII/MPR/1998 Tentang Hak Asasi Manusia, Bab 5.

105. One such law mentioned repeatedly was Telecommunications Law No. 5/1964, which states in Article 22, "Whoever reports news, or disseminates news, that was obtained without permission, or is not in the public interest, can be sentenced to a year in prison and a fine of Rp100,000." "Panji Tak Langgar Kode Etik," Kompas, February 20, 1999. Article 15 of this same law reads, "Whoever disseminates news that is unconfirmed, exaggerated, or incomplete, and that can provoke a public disturbance ... can be sentenced to up to two years in jail." "Polri Bentuk Tim, Wiranto Gerak, Pemimpim Majalah Panji Dijemput Paksa," Jawa Pos, February 20, 1999. In addition, both the wiretapper and the media outlets who aired the transcript could have been charged with violating Article 322 of the criminal code, which carried prison penalties for airing state secrets. See Indriyanto Seno Adji, "Pembocoran Berita dan Delik Pers," Kompas, February 23, 1999.

106. Quoted in “Soal Telpon, Habibie Marah Besar," Jawa Pos, February 24, 1999.

107. Adji, "Pembocoran Berita dan Delik Pers."

108. "Soal Telpon."

109. Conclusions from AJI discussion of the Panji case, Hotel Fortuna, Surabaya, February 25, 1999.

110. See "Hentikan Pemanggilan Wartawan," Suara Merdeka, February 24, 1999; Ichlasul Amal, "Interview: Jadi Sasaran Tembak," Jawa Pos, February 24, 1999.

111. "Anti-graft Body Has Ammo to Fight Further," SCMP, July 22, 1999; "ICW Distrusts Government's Stance on Ghalib Case," JP, July 22, 1999.

112. Janet Steele, "The Making of the 1999 Indonesian Press Law," Indonesia 94, no. 2 (October 2012): 1-22. The law, for example, guarantees press freedom as a basic civil right, codifies the right to protect sources and to access and disseminate information, and outlaws press censorship, banning, or attempts to block radio or television broadcasts. Law No. 40/1999. 
113. Karin Deutsch Karlekar, License to Censor: The Use of Media to Restrict Press Freedom (Washington, DC: Freedom House, September 2011), 31, https://freedomhouse.org/sites/default/ files/inline images/License\%20to\%20Censor\%20-\%20Media\%20Regulation\%20Report.

114. "Pemerkosaan di Bulan Mei 1998"; "Jejak Cendana di Banyuwangi: Pengakuan Desertir Kopassus," DëTAK, November 3-9, 1998.

115. "Golkar Unveils Four Names for 1999/2004 Presidency," JP, February 17, 1999; "Golkar Tests Waters on Habibie: Analysts," IO, February 22, 1999; "Gerakan Gembosisasi Itu Telah Dimulai," Jawa Pos, February 24, 1999.

116. See, for example, Sheila S. Coronel, "The Role of the Media in Deepening Democracy," United Nations Public Administration Network, 2003, http://unpan1.un.org/intradoc/ groups/public/documents/un/unpan010194.pdf; Silvio R. Waisbord, Watchdog Journalism in South America: News, Accountability, and Democracy (New York: Columbia University Press, 2000).

117. See, for example, "Pencalonan Habibie Sebagai Presiden: Sembilan Bulan Saja Habibie Tidak Mampu .. ." Merdeka, February 20, 1999; "Soal Penyadapan Telpon: Berdampak terhadap Pencalonan Habibie," Kompas, February 21, 1999; "Skandal Telepon, Kunci Karier Politik Habibie," Suara Merdeka, February 24, 1999; "Mungkin Sesaat Lagi Habibie Habis," Demokrat, February 1999; "Tesis: Ngotot Pun Habibie Akan Sulit," Oposisi, February 4-March 2, 1999; Dede N. P., Dahlan, and Junianto Setyadi, "Di Sana Clinton, di Sini Habibie," Bangkit, March $1-7,1999$.

118. Adam Przeworski, "Some Problems in the Study of Transition to Democracy," in Transitions from Authoritarian Rule, ed. Guillermo O'Donnell, Philippe C. Schmitter, and Laurence Whitehead (Baltimore: Johns Hopkins University Press, 1986), 58.

\section{Media in Retreat}

1. Personal observation, Aryaduta Hotel, Jakarta, June 22, 1999.

2. See, for example, the Team Seven member Ryaas Rasyid's interview in Gatra, September 22, 1998.

3. John McBeth, "Dawn of a New Age," FEER, September 17, 1998.

4. "Political Bills Offer No Guarantee of Fair Polls," JP, November 12, 1998.

5. See Michael Richardson, "Indonesia Braces for Vote on Reforms, NYT, November 9, 1998.

6. An exception was the United Development Party.

7. Jenny Grant, "Media Show Anger at Military Muscle," SCMP, November 13, 1998.

8. "Habibie Pledges to Stay until the End of 1999," JP, November 13, 1998.

9. "Political Bills Offer No Guarantee."

10. For example, Diah Purnomowati, Arif A. K., and Wenseslaus Manggut, "Mahasiswa Menuntut Parlemen Menentukan?” Tempo, November 9, 1998.

11. "Empat Tokoh Reformis Akhirnya Bertemu," Kompas, November 11, 1998; “'SI Tandingan' di Ciganjur," MI, November 11, 1998.

12. Cakrawala and Gema Senayan, ANteve, November 11, 1998; Liputan 6 Petang, SCTV, November 11, 1998; Syamsul Ma'arif, interview, SCTV, November 11, 1998; Sekilas Info and Seputar Indonesia, RCTI, November 11, 1998; Berita Nasional and Dunia Dalam Berita, TVRI, November 11, 1998.

13. Liputan 6 Petang, SCTV, November 12, 1998.

14. Bulletin Malam, RCTI, November 12, 1998.

15. MPR Resolution No. 11 (No. XI/MPR/1998) included an explicit directive to prosecute Suharto in Article 4.

16. Harmoko, speech before the MPR, November 13, 1998, broadcast on Liputan Sidang Istimewa MPR—Rapat Paripurna IV, TVRI, November 13, 1998.

17. Jakarta-based journalists, personal communication, November 13, 1998. See also Louise Williams, "Students Bay for Blood as Politicians Jostle for Position," SMH, November 14, 1998.

18. W. Kukuh Sanyoto, interview with author, Jakarta, May 19, 1999.

19. Berita Nasional, TVRI, November 13, 1998.

20. B. J. Habibie, televised address, Berita Nasional, TVRI, November 14, 1998.

21. On November 13, Indosiar announced that "out of control security forces" had beaten up several citizens described as "powerless," and explained that city bus drivers did not mind 
carrying students to demonstrations "precisely because they support the students." Fokus, Indosiar, November 13, 1998.

22. Aktualitas, ANteve, November 13, 1998.

23. Cakrawala, ANteve, November 13, 1998; Liputan 6 Petang, SCTV, November 13, 1998.

24. Berita Nasional, TVRI, November 12, 1998.

25. 7:00 p.m. report, TVRI, November 13, 1998.

26. Amien Rais, interview, Seputar Indonesia, RCTI, November 13, 1998.

27. Ibid.

28. The station did balance this perspective by interviewing Mar'ie Muhammad, a former finance minister but identified as a "former student activist," who demanded an explanation from the military and that those involved be put on trial. Seputar Indonesia, RCTI, November 13, 1998.

29. With the exception of two interviews with Abdurrahman Wahid, on Seputar Indonesia, RCTI, November 11, 1998, and Cakrawala, ANteve, November 14, 1998.

30. Liputan 6 Petang, SCTV, November 14, 1998.

31. See, for example, statements by MUI representatives (Berita Nasional, TVRI, November 13, 1998), Amien Rais (Berita Nasional, TVRI, November 13, 1998), and Agung Laksono (Liputan 6 Petang, SCTV, November 14, 1998).

32. Harmoko, statement broadcast on Liputan Sidang Istimewa MPR-Rapat Paripurna IV, TVRI, November 13, 1998.

33. Dunia Dalam Berita, TVRI, November 13, 1998.

34. Fokus, Indosiar, November 14, 1998.

35. B. J. Habibie, Aktualitas, ANteve, November 14, 1998.

36. "Calls Mount for Habibie and Wiranto to Step Down," JP, November 16, 1998; "Pressure on Habibie, Wiranto to Resign," AFP, November 14, 1998; Berita Nasional, TVRI, November 14, 1998; Persepsi, TVRI, November 14, 1998. Indosiar aired demands that Wiranto resign. Fokus, Indosiar, November 14, 1998. But coverage on the other private stations focused almost solely on the theme of unseen forces manipulating the students. Cakrawala, ANteve, November 14, 1998; Liputan 6 Petang, SCTV, November 14, 1998; Seputar Indonesia, RCTI, November 14, 1998.

37. Wimar Witoelar, "Black Friday Due to Impudence," JP, November 21, 1998.

38. Achmad Tirto Sudiro, Berita Nasional, TVRI, November 14, 1998.

39. Dunia Dalam Berita, TVRI, November 14, 1998.

40. Indosiar's coverage was an exception. See Fokus, Indosiar, November 14, 1998.

41. Alih Saham, "Rongrongan Gaya Orde Baru," WartaEkonomi, December 1, 1998.

42. Greg Earl, "Habibie Supporters Move to Control TV Networks," Australian Financial Review, November 24, 1998.

43. Imam Wahjoe L., “Tarik-Ulur Pasal Status Quo,” D\&R, January 25-30, 1999.

44. "Experts Discount Social Revolution but Urge Caution," JP, December 28, 1998. See also John McBeth, "Dawn of a New Age," FEER, September 17, 1998.

45. Djufri Asmoredjo, quoted in Karaniya Dharmasaputra and Edy Budyarso, "Tukar Guling dan Jurus Pelampung," Tempo, January 25, 1999.

46. Sander Thoenes, "Path for Free Elections Cleared," FT, January 28, 1999.

47. "Dinamika Pemilu Daerah," Kompas, May 7, 1999.

48. See, for example, "LDP [Liberal Democratic Party] Denies Pledge to Aid Golkar Scheme," JP, March 26, 1999; "Netralitas Pemilu Masih Terancam," Berita Buana, March 26, 1999; "PRD Akan Boikot Pemilu," Inti Jaya, March 26, 1999; "KIPP Protes Terhadap Parpol Diskriminasi," Inti Jaya, March 26, 1999; "Keterlaluan, Minta Gaji Rp 10 Juta," Merdeka, March 25, 1999; "Lho, Itu Kan Gaji Presiden," Merdeka, March 25, 1999; "Andi Mallarangeng Dimaafkan," Merdeka, March 25, 1999; "Mobil Anggota KPU Dibagikan," Merdeka, March 25, 1999; "ABRI Sedang Pilih-Pilih Partai," Merdeka, March 24, 1999; "Parpol Dilarang Terima Bantuan Asing," MI, March 24, 1999; "Parpol Tidak Boleh Terima Bantuan dari Negara Asing," MI, March 22, 1999; "Masih Sulit Hilangkan Kebiasaan Lama Golkar," Kompas, March 23, 1999; "Saksi Mata 'Money Politcs' di MPR: Diberi Jas dan Diajak Main Golf," Merdeka, March 22, 1999; "Tokohtokoh Barnas: Hanya Golkar Yang Mampu Sogok Anggota MPR Rp1 10 M," Merdeka, March 22, 1999. On KPU corruption, see "Tatkala Anggota KPU Bermobil Baru," MI, March 27, 1999; "Analysts Express Doubts about KPU's Credibility," JP, March 26, 1999; "Netralitas Pemilu Masih Terancam." 
49. This observation is based on a survey of evening news on five television stations and print coverage in six national newspapers from January to May 1999.

50. This figure is based on an estimate of 112 million votes cast. Seth Mydans, "Delays Mount in Indonesia Vote Count," NYT, June 27, 1999. The number of registered voters (127.6 million) is based on KPU figures. "KIPP Records 19,504 Violations," JP, July 10, 1999.

51. Carter was quoted in a number of articles at the time. "Carter Group Sees 'Festival of Democracy' in Indonesia," Kyodo News Service, June 9, 1999; Indira Lakshmanan, "Carter Gives a Good Grade to Indonesian Free Election," Boston Globe, June 9, 1999; "Japan Hails Indonesian Polls as Free and Fair," AFP, June 9, 1999; "Indonesia Poll Free and Fair: Japan's Top Monitor," Jiji Press Ticker Service, June 9, 1999; "Indon Election Free, Fair and a Triumph, Downer Declares," AAP Newsfeed, June 8, 1999; "Observers, Officials Say Indonesian Elections Free, Fair," Xinhua News Agency, June 8, 1999; “A Big Step for Indonesia,” LAT, June 9, 1999. 1999.

52. "Asian Observers Say Indonesian Polls Free Except in East Timor, Aceh," AFP, June 10,

53. These figures exclude violations in Aceh and East Timor. Atika Shubert, "Indonesia Tally Delayed Again amid Charges of Voter Fraud," JP/IHT, June 10, 1999. The number of polling stations is taken from "Komisi Pemilihan Umum," in the International Press Information Kit distributed at the JOMC, Aryaduta Hotel, Jakarta, May 18, 1999.

54. "Some Areas Demand that Polls Be Repeated," JP, June 10, 1999.

55. Ibid.

56. "Delays Plague Provincial Ballot Counts," JP, June 29, 1999.

57. "Observations on the Elections," anonymous submission to Joyo News Service, June 14, 1999, http//:www.asia-pacific solidarity.net/southeastasia/indonesia/netnews/1999/ and24_v3.htm\#More\%20reports\%20on\%20poll\%20violations\%20flow\%20in.

58. "How They Share the 462 DPR seats," JP, July 16, 1999; "Vote Gained by Top Five Parties for DPR," press release, JOMC, 6:02 p.m.-8:17 p.m., July 14, 1999.

59. "Some Areas Demand."

60. "Money Politics," editorial, JP, May 12, 1999. Further evidence of misappropriation came out in later scandals, such as Buloggate II. Bill Guerin, "Indonesia Prepares Black Sheep for Sacrifice," AT, October 26, 2001.

61. John McBeth, "Unpopular Decision: Election Overseers Allow Party Leaders to Decide Who Wins," FEER, May 6, 1999.

62. Reports from the General Election Commission's Joint Operations Media Center reinforced this impression. For example, its report on June 15 projected that PDIP, with 35.5 percent of the popular vote, would win 139 seats, while Golkar, with only 20.7 percent, would capture just 99 seats. "Indonesian Election: PDI-P Ahead with 58\% Votes Counted," press release, JOMC, June 15, 1999.

63. The Golkar-dominated Irian Jaya received thirteen seats for its population of two million, while the opposition-party stronghold of Jakarta was allocated only eighteen seats for its population of ten million-meaning there was one seat for every 282,000 registered voters in Jakarta versus one seat for every 77,000 in Irian Jaya. "How They Share." See also "Vote Gained by Top Five Parties for DPR," press release, JOMC, 6:02 p.m.-8:17 p.m., June 14, 1999.

64. See, for example, Robert Caro's description of how Lyndon Johnson won the 1948 US Senate race by holding back his tallies in the machine-controlled Rio Grande Valley until he knew his opponent's total and then trumping him with late reports. Robert A. Caro, The Years of Lyndon Johnson: Means of Ascent (London: Bodley Head, 1990), 181-91, 264-67, 307-17.

65. "Vote Gained by Top Five Parties for DPR," press release, JOMC, 7:20 a.m.-4:18 p.m., June 10, 1999.

66. Ibid.

67. "Vote Gained by Top Five Parties for DPR," press release, JOMC, 6:02 p.m.-8:17 p.m., June 14, 1999.

68. Based on the 1999 election law (UU No. 3/1999) and detailed in a National Election Commission decree (Surat Keputusan KPU No. 40/1999), the imbalanced electoral system gave each province one seat for every 450,000 residents and automatically granted an additional seat to all Level II voting districts in each province (kabupaten and kotamadya, or "regencies" and "townships"), regardless of population. Thus, dozens of regencies and townships in the less populous outer islands, versus almost none in Java and Bali, gained added value per vote. This electoral logic, as veteran observer Aristides Katoppo later affirmed, allowed pro-Golkar forces 
to delay release of final tallies from these secure outer island provinces until the count indicated the number of seats they would need to form a government. Aristides Katoppo, personal communication, Jakarta, June 9, 1999.

69. Data on the 1997 elections is from David Jenkins, “The New Indonesia: Soeharto's Legacy," SMH, October 27, 1998.

70. “Hidup PDI Perjuangan, Hidup Amien Rais,” Tempo, May 24-30, 1999.

71. Tanjung predicted that Golkar would win at least 102 of the 462 seats contested, compared to his estimate of 137 for PDIP. Shoeb Kagda, "Habibie Will Get Enough Votes: Golkar," Business Times (Singapore), July 3, 1999. 1999.

72. Gerry van Klinken, "Indonesia's Politics Enters a New Ball Game," opinion, JP, August 11,

73. Together the Islamic parties-United Development Party (PPP), Justice Party (PK), the Crescent Star Party (PBB), and several smaller ones-stood to win up to 12 percent of available seats. Kafil Yamin, "Presidential Aspirant Walks Political Minefield," IPS, July 1, 1999.

74. Kagda, "Habibie Will Get Enough."

75. "How They Share." Although the original number of MPR representatives that would select the next president had been set at seven hundred, the five provincial delegates from East Timor could not be chosen in September, given conditions there following the August 30 referendum, reducing total MPR membership to 695.

76. Three months later, Kompas estimated that the number of votes for a Habibie presidency, through coalition building, could be as high as 295 if one added Golkar's 120 to the United Development Party's possible 40 to 70 votes from representatives of provinces Golkar had won in the parliamentary elections and 65 from the sectoral representatives. Votes for Megawati, the paper predicted, would likely reach a maximum of 233. C. P. F. Luhulima, "Hitung-hitungan Presiden RI Medatang," Kompas, October 8, 1999.

77. For one exception, see Derwin Pereira, "Golkar Expecting Fewer Votes than PDIP," ST, June 10, 1999.

78. "Ballot Counting Runs at a Snail's Pace," JP, June 9, 1999; "Delays Plague Provincial Ballot Counts"; Seth Mydans, "Delays in Vote Count Have Indonesians Worried about Cheating," NYT, June 10, 1999. Though more balanced, the Financial Times also quoted KPU statements uncritically. Sander Thoenes, "Fret over Slow Result," FT, June 10, 1999. See also Grainne McCarthy, "Indonesian Market Euphoria Turns Sour as Vote Count Drags," DJ, June 10, 1999; John McBeth, "Counter-Productive: Frustrations Grow as Poll Count Drags On," FEER, July 7, 1999; "Political Bickering Clouds Indonesian Vote Count a Month after Polls," AFP, July 7, 1999.

79. Primadi's words were "Ada keganjilan ..., , which he translated for me at the time as "There is something fishy. ..." Riza Primadi, personal communication, Aryaduta Hotel, Jakarta, June 9, 1999.

80. Riza Primadi, personal communication, Aryaduta Hotel, Jakarta, June 10, 1999. I later asked why his station was paying so little attention to the reports of cheating that arrived each day from the various independent monitoring groups. He explained that there were too many; if SCTV began reporting some, they would have to report them all, and that would be "too much for one screen." Riza Primadi, personal communication, Aryaduta Hotel, Jakarta, June 12, 1999.

81. Hans (Pro-Kontra), Rio (Sehat), Ansel Deri (Rajawali), and Djoko Murnantyo (Penabur), personal communication, Jakarta, June 12, 1999.

82. Raymond Kaya, personal communication, Jakarta, June 12, 1999.

83. Even the Jakarta Post, one of the most critical voices in the Indonesian press, gave credibility to this explanation in extensive quotes from the KPU. "Ballot Counting Runs"; "KPU Agrees to Restart Selection of Interest Groups," JP, August 10, 1999. See also "Buyung Vows to Investigate Alleged KPU Corruption," JP, June 28, 1999; "Corruption out of Hand in Padang," JP, June 28, 1999.

84. Personal observation, Aryaduta Hotel, Jakarta, June 22, 1999.

85. "Pemilu 1999," Kompas.com, accessed July 27, 2014, http://indonesiasatu.kompas. com/pemilumasa.

86. While Tempo was the most aggressive of the mainstream newsweeklies in its coverage of election fraud, several others also produced cover-story exposés, including "Membonkar Kolusi di KPU," Tajuk, June 24, 1999, and "Pemilu Bagi-bagi Uang: Baramuli Digugat Utang Jutaan Dolar," Gamma, July 25, 1999. 
87. Ahmad Taufik and Verrianto Madjowa, "Sebar Uang, Pemilu Diulang," Tempo, June 21-27, 1999. Tempo's follow-up stories on Baramuli included "Baramuli, Sang Operator," Tempo, August 30-September 5, 1999," and "Faktor Baramuli Itu," Tempo, September 20-26, 1999.

88. "Pemilu 1999: Kesempurnaan Yang Retak," Tempo, June 28-July 4, 1999.

89. After its own investigation, Indonesia's Central Election Supervising Committee (Panwaspus) corroborated the Tempo reports and recommended legal action against Baramuli, who responded by threatening to sue Tempo for libel. "Election Watchdog Wants Baramuli Tried," IO, July 22, 1999.

90. Reluctance to promote competitors can also reduce follow-up reporting. For example, see Duncan McCargo, Politics and the Press in Thailand (London: Routledge, 2000), 168.

91. A conversation in May 2001 with Frans Seda, who served as finance minister to Suharto and economic advisor to Habibie, confirmed this reading and also explained why his party, PDIP, made little protest in response to Golkar's manipulation of the electoral process. Seda said that not only was PDIP disorganized at that time but also, after so many years of getting only a very small percentage of the vote in the elections of the New Order, party members were barely able to believe that the 1999 elections had been fair enough to allow their party to be in the lead at all. Personal communication, Madison, WI, May 19, 2001.

92. "10 Parties 'Shared Rp 109b from Bulog," JP, March 16, 2002; Marianne Kearney, “Media 'Also Received Bulog Funds,"” ST, June 20, 2002.

93. Wahid reportedly asked Wiranto for "assurances that the military would stay neutral right up to the presidential election." Derwin Pereira, "Gus Dur's Hush-Hush Talks with Wiranto," ST, June 10, 1999.

94. Personal observation, Jakarta, July 1999. 1999.

95. Keith B. Richburg, "Election Protest Sparks Violence in Indonesia," IHT/WP, July 2,

96. Personal observations at the scene of the shooting. Forum Keadilan published a closeup photo of the violence on its cover on July 11, 1999.

97. Desi Anwar, "Indonesian Politics a Far Cry from Democracy," JP, July 22, 1999.

98. John Aglionby, "Indonesia in Turmoil over Poll Dispute," Guardian, July 26, 1999. The dissenting parties together won 6.38 percent of the approximately 117 million votes cast. The seventeen parties who did sign off won 93 percent. Four parties did not show up. Jeremy Wagstaff and Puspa Madani, "Several Indonesian Parties Refuse to Ratify Election, Delaying Results," WSJ, July 27, 1999; Anwar, "Indonesian Politics"; "Political Bickering." See also Nicole Gaouette, "Sour Grapes Spoil Indonesia Election Result," Christian Science Monitor, July 28, 1999.

99. "KPU Agrees to Restart."

100. Jusuf Wanandi, “The Next Move in Indonesian Politics," opinion, JP, July 28, 1999.

101. Ibid. Both alternatives - that is, allowing the winning party in each region to take all five seats for that region and the KPU's preference to assign the five seats per region to reflect the votes won by all parties-would add to Golkar's lead.

102. "KPU Agrees to Restart."

103. Ibid.

104. Lukas Luwarso, personal communication, July 24, 1999; Haris Jauhari, email correspondence, August 11, 1999.

105. Haris Jauhari, email correspondence, August 16, 1999.

106. Haris Jauhari, personal communication, Jakarta, July 28, 1999.

107. Haris Jauhari, personal communication, Jakarta, July 27, 1999.

108. Ibid.

109. Lukas Luwarso, email correspondence, August 13, 1999.

110. Haris Jauhari, email correspondence, August 11, 1999.

111. Luwarso, email correspondence, August 13, 1999; Jauhari, email correspondence, August 16, 1999.

112. Letter to the head of the General Election Commission, "Pernyataan sikap 20 organisasi wartawan menolak keberadaan utusan golongan wartawan di MPR," Jakarta, August 11, 1999. The letter was signed by Lukas Luwarso (Alliance of Indonesian Journalists), Haris Jauhari (Indonesian Television Journalists Association), Budiman S. Hartoyo (Indonesian Journalist Association-Reformasi), Arbain Rambey (Indonesian Photojournalists Association), Ichsan Loulembah (Indonesian Alliance of Radio Journalists), and M.A. Nasution, representing the Indonesian Press Society, a group consisting of fifteen journalists' organizations. 
113. Haris Jauhari, email correspondence, August 20, 1999.

114. Letter to the head of the General Election Commission.

115. Jauhari, email correspondence, August 20, 1999.

116. With the elimination of East Timor's five provincial seats, the minimum number of MPR votes Habibie would need to secure the presidency was 348 (out of 695). Eleven days before the October 20 election, Kompas predicted that Habibie was likely to win at least 333 votes, including 70 from the provincial candidates of the 14 provinces Golkar had won, and "as many as 65" from the sectoral groups whose representatives "for the most part," Kompas said, "had been chosen by B.J. Habibie." By contrast, PDIP's candidate, Megawati, would likely win only 233 votes: 153 from her own party, 55 from provincial delegates, 15 now expected from the National Awakening Party (Wahid's party), and up to 10 from two of the smaller partiesthe Justice and Unity Party and the Love the Nation Democratic Party. The paper predicted the military's 38 representatives would not support her. Luhulima, "Hitung-hitungan Presiden RI Mendatang."

117. Notable exceptions included Tempo, whose June investigative reports are discussed above, and the Jakarta Post, which did not play up accounts of irregularities, but did publish regular reports as they came in.

\section{Baligate and All the Gates}

1. Quoted in David Jenkins, “The Awful Choice," Age, October 19, 1999, https://www. newspapers.com/newspage/123512452/.

2. “60,000 Troops to Secure MPR Session," JP, September 25, 1999.

3. Adam Przeworski, "Some Problems in the Study of Transition to Democracy," in Transitions from Authoritarian Rule, ed. Guillermo O'Donnell, Philippe C. Schmitter, and Laurence Whitehead (Baltimore: Johns Hopkins University Press, 1986), 58.

4. J. Samuel Valenzuela, "Democratic Consolidation in Post-transitional Settings: Notion, Process and Facilitating Conditions," in Issues in Democratic Consolidation: The New South American Democracies in Comparative Perspective, ed. Scott Mainwaring, Guillermo O'Donnell, and J. Samuel Valenzuela (Notre Dame, IN: University of Notre Dame Press, 1992), 9.

5. Ibid., 9-10.

6. Ahmad Taufik and Verrianto Madjowa, "Sebar Uang, Pemilu Diulang," Tempo, June 21-27, 1999.

7. "Bank Bali Dibobol Habibie," SiaR email list, July 30, 1999.

8. "Bank Bali Believed to Be Involved in 'Money Politics,"” Kompas, July 31, 1999.

9. "Indonesia: Golkar Executive Denies Party Got Money from Bank Bali," Antara, August 3, 1999. That evening, SCTV forced Bank Indonesia's governor, Sjahril Sabirin, to comment. "Sjahril Vows Probe into IBRA Scandal," JP, August 4, 1999.

10. "Baligate: The Political Fallout," ST, August 15, 1999.

11. “The People's Money,” JP, August 11, 1999.

12. Sanjoto Sastromihardjo, "Skandal Bank Bali 'Dipindah-rel-kan'?," Business News, August 10, 1999, reprinted in Reformasi dalam Perspektif Sanjoto (Jakarta: Yayasan Orbor Indonesia, 1999), 248-50; Jay Solomon, "In Indonesia, Crisis and Corruption Are Creating Financial Vigilantes," WSJ, September 21, 1999. 1999.

13. "Prominent Figures Responsible for Bank Bali Scam: Analyst," Asia Pulse, August 10,

14. Solomon, "In Indonesia, Crisis and Corruption."

15. "Golkar Terancam Diskualifikasi," SiaR email list, August 4, 1999.

16. "Tim Habibie Bobol Bank Bali," Xpos no. 27/II, August 8-14, 1999. 1999.

17. "IBRA Says Bank Bali US $\$ 80$ Mln Commission May Be Cancelled," AFP, August 9,

18. “Delapan Pejabat BPPN Diperiksa," SP, August 13, 1999.

19. Kevin O'Rourke, Reformasi: The Struggle for Power in Post-Soeharto Indonesia (Crows Nest, Australia: Allen \& Unwin, 2003), 247.

20. O'Rourke, Reformasi, 248. Baramuli was also the main figure in Tempo's June Sulawesi election fraud exposé.

21. "Beredarnya Rekaman Ghalib-Habibie: Halo, Ghalib dan Habibie di Sini," Panji Masyarakat, February 24, 1999. 
22. "The 10 Suspects," ST, August 15, 1999. See also Reiner Simanjuntak, "Frustration Escalates as Bank Bali Scandal Drags On," JP, September 20, 1999.

23. "The People's Money." 1999.

24. "Parliament's Special Team Should Not Disappoint Traders," Kompas, September 23,

25. Solomon, "In Indonesia, Crisis and Corruption."

26. "Pertarungan Golkar 'Hitam' dan 'Putih,"” Suara Merdeka, August 11, 1999; "Baligate: The Political Fallout," ST, August 15, 1999.

27. "Activist Says Marzuki Leaked Bank Bali Story," JP, August 13, 1999.

28. Wimar Witoelar, "The Role of the Media and the Recent Changes in Indonesian Politics," University of Wisconsin-Madison, Center for Southeast Asian Studies Friday Forum Lecture Series, October 22, 1999.

29. Solomon, "In Indonesia, Crisis and Corruption"; "Yudono Defends Keeping Full PwC Audit under Wrap," JP, September 30, 1999.

30. Witoelar, "Role of the Media."

31. National Democratic Institute, The 1999 Presidential Election and Post-election Developments in Indonesia (Washington, DC: National Democratic Institute, November 28, 1999), https://ndi. org/sites/default/files/1079_id_preselect_5.pdf.

32. "Rudy Says Journal Exists, Keeps Mum on Contracts," JP, September 10, 1999; Simanjuntak, "Frustration Escalates."

33. "House Team Says Baramuli Is Involved in Bank Bali Scandal," JP, September 18, 1999.

34. "Yudono Defends."

35. Quoted in Simanjuntak, "Frustration Escalates." 1999.

36. Sander Thoenes, "Military's Power Undimmed by Humiliations," FT, September 21,

37. Ibid.

38. "Menanti Runtuhnya Rupiah," Kontan, September 20, 1999; "Bocoran Pricewaterhouse dan Jejak Sang Menteri," Tempo, September 13, 1999. "Baramuli off the Hook-Intervention, Cover-Ups Mar Baligate Revelation," IO, September 23, 1999; "Ronde Pamungkas Bank Bali," Tempo, September 27, 1999.

39. Interview with Tony A. Prasetyantono, "All the President's Men Simply Buy Time," JP, September 24, 1999.

40. "Parliament's Special Team."

41. Law No. 40/1999.

42. "TNI" replaced "ABRI" (Angkatan Bersenjata Republik Indonesia, or Armed Forces of the Republic of Indonesia) as the name for Indonesia's military in April 1999, reflecting a new separation from the national police.

43. Thoenes, "Military's Power Undimmed."

44. "State Security Bill Faces Tough Protest," JP, September 15, 1999.

45. "Indonesian Students Return to Parliament to Protest," AFP, September 17, 1999.

46. Ted Bardacke, "Indonesian Students Killed in Protest against New Law," FT, September 24, 1999.

47. "More Antisecurity Bill Protests Hit Jakarta," JP, September 16, 1999; "PAN and PKB Reject State Security Bill," JP, September 17, 1999.

48. "Parties Rethink State Security Bill," JP, September 20, 1999.

49. "Indonesian Parliament Approved Army-Backed Bill on State Security," AFP, September 23, 1999.

50. "A Dubious Accomplishment," JP, September 24, 1999.

51. J. Wagstaff and M. Puspa, "Thousands of Indonesians Protest Security Bill Passed by Parliament," WSJ, September 24, 1999.

52. "Warning Shots, Teargas Fired to Disperse Indonesian Protests," AFP, September 23, 1999.

53. "University to Probe Death of Student in Jakarta Military Shooting," AFP, September 25, 1999.

54. "Akhirnya, Pemerintah Tunda RUU PKB," Kompas, September 25, 1999.

55. "Deliberation of State Emergency Bill to End," JP, September 22, 1999; "Indonesian President Delays Approval of the New Security Bill," AFP, September 24, 1999.

56. "Groups Lash Out at President, Military Chief over Protest Violence," AFP, September 25,1999 . For this statement and a list of the groups that issued it, see Yayasan Selendang Lila, 
"Pernyataan Solidaritas untuk Demokrasi Indonesia," Jaringan Pendidikan Lingkungan (blog), September 26, 1999, https:/groups.yahoo.com/neo/groups/jpl/conversations/messages/383.

57. "Indonesian President Delays Approval"; "Akhirnya, Pemerintah Tunda RUU PKB."

58. Juwono Sudarsono, quoted in "Habibie Ready to Give Up Power, Juwono Says," JP, September 27, 1999.

59. Mustofa, "Menimbang Kemungkinan Megawati," Kompas, October 15, 1999.

60. Jeremy Wagstaff, "Dark before Dawn: How Elite Made a Deal before Indonesia Woke Up," WSJ, November 2, 1999.

61. Jose Manuel Tesoro, "All Bets Are Off: In the Race for the Presidency, New Power Balances Are Surfacing," Asiaweek, October 15, 1999.

62. Jenkins, "Awful Choice."

63. Witoelar, "Role of the Media."

64. Quoted in John McBeth and Margot Cohen, "Unlikely Victor," FEER, October 28, 1999.

65. Witoelar, "Role of the Media."

66. National Democratic Institute, "1999 Presidential Election," 16.

67. Tesoro, "All Bets Are Off."

68. Nisid Hajari, "Taking It Right Down to the Wire," Time, October 25, 1999.

69. A "former political party leader" quoted in Jenkins, "Awful Choice." 1999

70. "Press Freedom, Elections Are Habibie's Only Good Points: Poll," AFP, October 17,

71. Hajari, "Taking It Right Down."

72. David Lamb, "On Election Eve, Who Will Head Indonesia Is in Doubt," LAT, October 19, 1999.

73. Quoted in Jenkins, "Awful Choice."

74. Ibid.

75. Wagstaff, "Dark before Dawn." For more on backroom maneuvering during these two days, see "What Went On behind the Scenes," Business Times (Singapore), October 22, 1999.

76. Ron Moreau, "Duel of the Shadow Puppets: Don't Trust Appearances in This Week's Presidential Contest," Newsweek International, October 25, 1999.

77. Wagstaff, "Dark before Dawn."

78. Ibid.

79. "Megawati Party Accepts Defeat with Grace, Angry Followers Go on Rampage," AFP, October 20, 1999.

80. Ahmad Taufik and Verrianto Madjowa, "Sebar Uang, Pemilu Diulang," Tempo, June 21-27, 1999; Tempo staff, "Pemilu 1999: Kesempurnaan Yang Retak," Tempo, June 28-July 4, 1999.

81. "Election Watchdog Wants Baramuli Tried," IO, July 2, 1999. 1999.

82. "Panwas: 'Tindak Baramuli!' Diduga Lakukan Money Politics," Suara Merdeka, July 2,

83. The New Oxford American Dictionary, 3rd ed. (2010), s.v. "scandal."

84. "Baligate: The Political Fallout," ST, August 15, 1999.

85. "Election Watchdog."

86. "10 Parties 'Shared Rp 109b from Bulog," JP, March 16, 2002. On the diversion of funds to over two dozen media outlets and numerous religious organizations, see Marianne Kearney, "Media 'Also Received Bulog Funds," ST, June 20, 2002.

87. "10 Parties."

\section{Scandal and Democratic Consolidation}

1. “DPR Receives PwC's Full Audit Report," JP, October 20, 1999.

2. The joint committee formed from DPR Commissions II and IX.

3. "DPR Receives PwC's Full Audit Report."

4. "Indonesian President Urges Media to Be Tough with New Government," AFP, October 27, 1999.

5. Quoted in "Wahid's Strategy," AFP, February 14, 2000.

6. "Wiranto's Exit," editorial, JP, February 15, 2000.

7. “House Won't Oust Wahid: Speaker," IO, January 27, 2000. See also "Lower House to Summon Commander over US Envoy’s Coup Rumour,” Rakyat Merdeka, January 19, 2000. 
8. "Wahid Says Sorry as Former Suharto Party Flexes Its Muscles," AFP, July 21, 2000.

9. George J. Aditjondro, "Focusing on Bulog, Brunei Scams," JP, January 10, 2001.

10. "PBB Seeks to Impeach Gus Dur over Communism Issue," JP, April 15, 2000.

11. See "Progress Will Require a Change of Attitude from Gus Dur," IO, June 28, 2000. For more corruption under Wahid, see George J. Aditjondro, "Post-Suharto Multi-party Corruption in Indonesia: The Absence of Control Mechanisms," paper presented at CAPSTRANS conference, University of Wollongong, NSW, Australia, December 4-6, 2000.

12. Achmad Sukarsono, "Outgoing Presidential Aide Warns of Indonesia Plot," Reuters, May 30, 2000.

13. "Bulogate," JP, May 30, 2000.

14. Johan Budi et al., "Return of the Masseur," Tempo, October 16-22, 2000.

15. Nuruddin Lazuardi, "Marathon Questioning for 'Abducted' Bulog Thief," Dëtikworld, May 26, 2000.

16. Marianne Kearney, "Weapons against Corruption (Indonesia), Where Have All the Rupiah Gone?” ST, May 20, 2001.

17. "Bulogate."

18. Budi et al., "Return of the Masseur."

19. Early uses of the term used the spelling "Bulogate." By the time the second major Bulog scandal broke, the most common spelling for both used the double $g$.

20. Lukamnul Hakim et al., "The Plot Thickens in the Case of Bulog's Missing Millions," Detikworld, May 25, 2000.

21. Devi Asmarani, "Lawmakers Launch New Probe into Bulog," ST, June 10, 2000.

22. "Gus Dur Told to Explain Bulogate," JP, May 31, 2000.

23. Asmarani, "Lawmakers Launch New Probe."

24. "House Speaker Akbar Hit by Graft Allegations," JP, July 10, 2000. 2000 .

25. "ICW Urges Probe on Corruption Allegedly Involving House Chief," IO, September 22,

26. "Akbar Dismisses Call for Probe into Alleged Scams," JP, January 18, 2001.

27. "President's OK Needed to Question Akbar," JP, February 20, 2001.

28. "PDI-P, PKB Propose Probe into Other Scandals, Bombings," JP, February 3, 2001. See also D. Sangga Buana, Rin Hindrayati, and Lyndal Meehan, "Bank Liquidity Assistance Scandal: 16 Banks Tamper with Evidence,” Detikworld, June 12, 2000.

29. Quoted in "PDI-P, PKB Propose Probe."

30. "Heboh Foto Intim Gus Dur-Aryanti," Gatra, August 28, 2000; "Aryanti Boru Sitepu: Gus Dur Bohongi Saya," Panji Masyarakat, September 6, 2000; "Aryanti Sengaja Menghina Presiden?," Forum Keadilan, September 10, 2000. See also Richard Lloyd Parry, "Clerical President Denies Sex Scandal," Independent (UK), August 30, 2000, https://www.independent.ie/worldnews/clerical-president-denies-sex-scandal-26112725.html.

31. "Mahfud Clarifies Allegation of Golkar's Misuse of Funds," JP, February 14, 2001. Mahfud later acknowledged his source as the coordinating minister for the economy and former Bulog chief, Rizal Ramli.

32. "Rais Backs Investigation into Golkargate," IO, February 22, 2001.

33. Calvin Sims, "Indonesian President Goes on TV to Deny Corruption Allegations," NYT, January 31, 2001.

34. Jay Solomon and Puspa Madani, "Probe Targets Money Scandals Tied to Indonesia's Wahid," AWSJ, August 28, 2000.

35. Tom Wright and I. Made Sentana, "Exclusive: Indonesian Lawmakers Say Wahid Broke Law," DJ, January 31, 2001.

36. Dini Djalal, "Wahid Keeps a Nation Guessing as to His Fate," Bangkok Post, May 30, 2001; Lindsay Murdoch, "Wahid Apology Fails to Satisfy MPs," SMH, March 29, 2001. 2000 .

37. Quoted in "Hadiah Istimewa Gus Dur untuk Wartawan: Kritik," Kompas, February 18,

38. Quoted in "Juwono Lashes Out at Private Television Stations," JP, April 17, 2000. 2000.

39. Quoted in "There Is a Print Media Conspiracy to Unseat Gus Dur: PKB," JP, October 6,

40. Quoted in "President Abdurrahman Says Some Media Get Paid to Spread Lies," JP, November 19, 2000.

41. Quoted in "Mahfud Blasts Media for Being Anti-government," IO, January 22, 2001. 
42. "Indonesia Bars Foreign Journalists from Hotspots," Reuters, January 26, 2001.

43. Quoted in "Banser Para-military Preparing to Come to the Aid of 'No Worries' Wahid," Laksamana.Net, January 22, 2001, http://joyonews.org/JoyoNews.php?link=31170.

44. "President Orders 'Self-Censorship' of State Television Network," Tempo, March 26, 2001.

45. Quoted in "Wahid a Victim of Prejudiced Press," Bangkok Post, March 25, 2001.

46. Quoted ibid.

47. "Gus Dur Plans to Sue Media for Spreading Lies," JP, May 10, 2001.

48. Quoted in "Govt Establishes Media Watchdog," IO, May 11, 2001.

49. "Order Issued to Restore Security," JP, May 29, 2001; "Character Assassination and Criticism in the Indonesian Media," editorial, Laksamana.Net, June 25, 2001, http://joyonews. org/JoyoNews.php?link=39495.

50. "A Chronology of Wahid's 21 Months in Power," AFP, July 24, 2001.

51. Ibid.

52. Richard Lloyd Parry, "Embattled Wahid Says He Will Not Stand Down," Independent (UK), July 23, 2001.

53. “Gus Dur Suspends MPR, DPR,” JP, July 23, 2001.

54. "Indonesian Military Opposed to Wahid's Decree," AFP, July 23, 2001.

55. "Character Assassination and Criticism."

56. "Press Censorship," editorial, JP, January 29, 2001.

57. "Serambi Redaksi," Gatra, September 11, 2000. For an extended interpretation of the possible motives behind press coverage of Wahid's alleged affair, see Nicole Andres, "MediaElite Interactions in Post-authoritarian Indonesia" (PhD diss., Murdoch University, 2016), $164-76$.

58. Laksamana Sukardi, "Will Mega Survive?," Laksamana.Net, October 22, 2001, http:// joyonews.org/JoyoNews.php?link $=45856$. 2001.

59. John McBeth, "Indonesia's Golkar Party Faces Another Scandal," FEER, December 13,

60. Bill Guerin, “Indonesia Prepares Black Sheep for Sacrifice,” AT, October 26, 2001.

61. Sukardi, "Will Mega Survive?"

62. Guerin, "Indonesia Prepares Black Sheep."

63. "AG to Summon Akbar, Wiranto," JP, October 11, 2001.

64. "Under Mega's Wing?," Tempo, October 30-November 5, 2001.

65. "Bulog Funds Were Spent on Food Assistance: Akbar," JP, October 11, 2001.

66. Guerin, "Indonesia Prepares Black Sheep."

67. "The Fall of Tanjung and Folly of Mega?," opinion, Laksamana.Net, October 25, 2001, http://joyonews.org/JoyoNews.php?link=46106.

68. "PDI Perjuangan Indecisive on Akbar Corruption Case," JP, October 31, 2001.

69. "AG to Summon Akbar, Wiranto."

70. “Akbar Denies Golkar's Involvement in Reported Bulog Fund," JP, October 17, 2001.

71. "Audit Exposes Graft in Attorney General's Office," Laksamana.Net, December 3, 2001, http://joyonews.org/JoyoNews.php?link $=48043$.

72. Quoted in D. Karaniya et al., "Sepuluh Lembar Cek di Tiga Skenario," Tempo, October 29-November 4, 2001.

73. Tertiani Z. B. Simanjuntak, "Akbar, Wiranto Grilled over Alleged Graft," JP, November 1, 2001. The foundation's name had many spellings in subsequent reports, but "Raudatul Jannah" appears to be the "correct" spelling insofar as the foundation existed to begin with.

74. Tiarma Siboro, "Damaging Revelations for Akbar," JP, November 20, 2001.

75. Karaniya et al., "Sepuluh Lembar Cek."

76. "Under Mega's Wing?"

77. Guerin, "Indonesia Prepares Black Sheep."

78. "Akbar Urged to Relinquish His Posts,"JP, October 26, 2001.

79. Warren Caragata, "Sticky Money," Asiaweek, November 9, 2001.

80. Quoted in "Akbar Denies Issuing Receipts in Bulog Funds Disbursement," JP, November 19, 2001.

81. "The Elite Pact's Pinocchio Problem," Laksamana.Net, November 21, 2001.

82. "Golkar to Set Up 'Rival' Special Committee on Bulog Scandal," JP, December 1, 2001.

83. “Calling Golkar's Bluff," editorial, JP, December 5, 2001. 
84. See the discussion of "local media" reporting in "Court Postpones Verdict on Case vs. Indonesia Ctrl Bk Head," AP, December 5, 2001.

85. "Corruption in Indonesia: The Wheel Turns," Economist, January 10, 2002.

86. "Mega Won't Help Tanjung," Laksamana.Net, January 10, 2002, http://joyonews.org/ JoyoNews.php?link $=49490$.

87. See, for example, Forum Keadilan's cover image showing Tanjung on the verge of tears. "Akhir Perjalanan Bung Akbar," Forum Keadilan, March 17, 2002. See also coverage by Tajuk, Panji Masyarakat, and DëTAK during this period.

88. "Akbar Terpojok, Siapa Senang," Tempo, November 26-December 2, 2001.

89. Yellow (the color of Tanjung's matador costume) is Golkar's color, and green (the color of the cape) is the color associated with Islam in Indonesia (Raudatul Jannah is an Islamic foundation, albeit most likely a fictional one). "Jurus Matador Akbar," Tempo, January 21-27, 2002.

90. "Mega Won't Help Tanjung."

91. Ibid.

92. Richel Langit, “Indonesia: See No Evil, Speaker No Evil,” AT, January 31, 2002.

93. Ibid.

94. “Tanjung Inquiry Still Unlikely," Laksamana.Net, March 5, 2002, http://joyonews.org/ JoyoNews.php?link=52201.

95. "Corruption in Indonesia."

96. "Former Indonesian President Quizzed over Graft," Reuters, February 25, 2002.

97. D. Karaniya, Adi Prasetya, and Levi Silalahi, "Endgame for Akbar," Tempo, March 12-18, 2002. 2002.

98. Vaudine England, "Akbar Detention Sign of New Reformist Zeal," SCMP, March 9,

99. Langit, "Indonesia: See No Evil."

100. See, for example, "Sikap Golkar Tergantung PDIP," Tempo, March 9, 2002; "Sekjen PDI P: Sikap Kami Tak Berubah,” Gatra, March 17, 2002.

101. Gendur Sudarsono, Andari Karina Anom, and Rian Suryalibrata, "Akbar First, Golkar Next?," Tempo, March 12-18, 2002.

102. Karaniya, Prasetya, and Silalahi, "Endgame for Akbar." 2002.

103. Marianne Kearney, "Returned Bulog Funds 'a Bid to Get Akbar Off,"” ST, March 11,

104. Yogita Tahilramani, "Akbar Defiant as His Graft Trial Kicks Off," JP, March 26, 2002.

105. Edy Budiyarso and Syarief Amir, "He Is No Mandela," Tempo, March 12-18, 2002. 2002.

106. Kurniawan Hari, "House Leaders Rule Akbar Will Retain Speakership," JP, March 27,

107. Muninggar Sri Saraswati and Yogita Tahilramani, "Foul Play Apparent in Akbar's Case," JP, March 16, 2002.

108. "Rahardi Ramelan's Uphill Battle," Tempo, March 26-April 1, 2002.

109. Marianne Kearney, "Five Graft Cases in Recent Days: Jakarta Shows It Means Business," ST, March 20, 2002.

110. Kurniawan Hari, "Legislators Move to Summon Mega," JP, March 27, 2002.

111. Annastashya Emmanuelle, "Bulog Funds Went to Individuals: PDI Perjuangan," JP, April 3, 2002.

112. Tahilramani, "Akbar Defiant."

113. Ahmad Taufik, Hadriani Pudjiarti, and Ardi Bramantyo, "Justice for Akbar?," Tempo, March 26-April 1, 2002.

114. Sudarsono, Anom, and Suryalibrata, "Akbar First, Golkar Next?"

115. “'Lame-Duck Akbar' Back on Stage," editorial, Laksamana.Net, April 6, 2002, http:// joyonews.org/JoyoNews.php?link=53760.

116. Tahilramani, "Akbar Defiant."

117. Taufik, Pudjiarti, and Bramantyo, "Justice for Akbar?"

118. Andrew Marshall, "Trial of Scandal-Hit Indonesia Bankers Ended," Reuters, December 1, 1999.

119. Muninggar Sri Saraswati, “'Akbar Tried to Make Me Lie,” JP, April 24, 2002. 2002.

120. Tertiani Z. B. Simanjuntak, "Rahardi Handed Light Sentence for Graft," JP, December 26, 
121. Saraswati, “'Akbar Tried to Make Me Lie.”

122. Wens Manggut, Levianer Silalahi, and Ecep S. Yasa, "Buloggate II: Forty Billion Lies," Tempo, May 14-20, 2002. 2002.

123. Annastashya Emmanuelle, "Ruling Party Hesitant to Investigate Akbar," JP, June 5, 2002.

124. Muninggar Sri Saraswati, "Witness Admits Telling Lies to Save Akbar," JP, May 8, 2002.

125. Tertiani Z. B. Simanjuntak, "Habibie’s Testimony Damaging for Akbar," JP, May 21,

126. Nafik and Fabiola Desy Unidjaja, "How Can House Be Led by a Convicted Criminal?,"” JP, September 6, 2002.

127. Andreas Harsono, "Indonesian Journalists Troubled by Return of Ministry of Information," Freedom Forum, August 22, 2001.

128. Ibid.

129. "Indonesia's Media: Freedom or Professionalism?," Laksamana.Net, December 10, 2001, http://joyonews.org/JoyoNews.php?link $=48361$.

130. Kurniawan Hari, "Govt Moves to Rein In Press," JP, December 7, 2001.

131. Kurniawan Hari, "Press Council Asks to Handle Disputes," JP, December 8, 2001.

132. Article 19, "Freedom of Expression and the Media in Indonesia," Article 19 (London and Jakarta: AJI, 2005), 44.

133. Lindsay Murdoch, "Timor's Lost Children," Age (Melbourne), June 18, 2001.

134. Lindsay Murdoch, "The Horror of Aceh: The Day the Soldiers Came," Age (Melbourne), May 14, 2001.

135. Quoted in "Media 'Ready to Fight' for Freedoms," Laksamana.Net, March 26, 2002, http://joyonews.org/JoyoNews.php?link=53230.

136. "A Chill Wind in Jakarta," editorial, WSJ, April 2, 2002.

137. "New Ministers Commend Role of Public Criticism," JP, November 4, 1999.

138. Achmad Sukarsono, "Indonesia's Megawati Puts Up More Barriers against Media," Reuters, January 29, 2002.

139. Quoted ibid.

140. Quoted in "Media 'Ready to Fight."”

141. "Source of Presidential Donation Questioned," JP, March 19, 2002. 2002.

142. Kurniawan Hari, "House Leaders Rule Akbar Will Retain Speakership," JP, March 27,

143. "Megawati's Military Donation Explained," Laksamana.Net, March 28, 2002, http:// joyonews.org/JoyoNews.php?link=53346. 2003

144. Ray Anthony Gerungan, "Why Megawati Deserves Another Term," JP, October 15,

145. Andreas Ufen, "Political Parties in Post-Suharto Indonesia: Between Politik Aliran and 'Philippinisation,'” South East Asia Research 16 (2008): 1.

146. In late 1999, Transparency International's annual "demand-side corruption index" gave Indonesia a rating of only 1.7, tied for last place with Azerbaijan out of the 99 AsianPacific countries included. Eduardo Lachica, "Exporters' Bribery Habits Are Scrutinized in Asia," AWSJ, October 26, 1999.

\section{Media And Civil Society}

1. Madeleine Albright, speech delivered at the conference "Towards a Community of Democracies," Warsaw, June 26, 2000, quoted in Jane Perlez, "Vast Rally for Democracy Opens in a Polish Castle," NYT, December 26, 2000.

2. Adam Przeworski, Democracy and the Market: Political and Economic Reforms in Eastern Europe and Latin America (Cambridge: Cambridge University Press, 1991), 12.

3. Larry Diamond, Juan J. Linz, and Seymour Lipset, Democracy in Developing Countries: Latin America (Boulder, CO: Lynne Reiner, 1989), 8; Larry Diamond, "Elections without Democracy: Thinking about Hybrid Regimes," Journal of Democracy 13 (April 2002): 21-25.

4. This exercise characterizes what theorists have termed "electoral authoritarianism." See, for example, Andreas Schedler, The Politics of Uncertainty: Sustaining and Subverting Electoral Authoritarianism (New York: Oxford University Press, 2013). 
5. Alwi M. Dahlan, interview with author, Jakarta, July 29, 1999.

6 . For stories on scandals undermining President Yudhoyono's attempts at dynasty building and his party's hopes of retaining power, see Peter Alford, "SBY's Son Edhie Baskoro Quits as Scandal Rages," Australian, February 15, 2013; Rendi A. Witular, "House of Yudhoyono/ Wibowo in the Making," JP, November 15, 2010.

7. Dan Slater and Erica Simmons, "Coping by Colluding: Political Uncertainty and Promiscuous Powersharing in Indonesia and Bolivia," Comparative Political Studies 30 (2012): 2-3.

8. Patrick Ziegenhain, "The Indonesian Legislature's Impact on Democratic Consolidation," in Democratization in Post-Suharto Indonesia, ed. Marco Bünte and Andreas Ufen (London: Routledge, 2009), 46.

9. Aristo Pangaribuan, "Court 'Brokers' Need to Be Broken," JG, December 2, 2009.

10. In 2009, Leo Batubara, former deputy chair of the National Press Council, cited thirtyseven articles in the criminal code alone that could send journalists to jail, and said that a pending bill to revise the code contained sixty-one articles that carried similar criminal sanctions. Interview with author, Jakarta, July 9, 2009.

11. Article 19, "Article 19 Applauds the Decision of the Indonesian Supreme Court to Overturn the Criminal Libel Conviction of Bambang Harymurti," Article 19, March 2, 2006.

12. "Indonesian Dispute Resolution 2015," Conventus Law, January 29, 2016; Human Rights Watch, Turning Critics into Criminals: The Human Rights Consequences of Criminal Defamation Law (New York: Human Rights Watch, 2010), https://www.hrw.org/report/2010/05/03/turning-critics-criminals/ human-rights-consequences-criminal-defamation-law.

13. Other 2008 laws adding dozens of new provisions to silence the press included the Access to Public Information Law, the Pornography Law, and the State Secrecy Bill.

14. Julia Suryakusuma, "A Singer's Gyrating Rattles Indonesia," IHT, May 14, 2003; "One Step Forward ... Two Steps Back," Tempo, October 1-6, 2008.

15. "One Step Forward"; Devi Asmarani, "Will Jakarta's Anti-porn Bill Protect or Repress?," ST, January 2, 2007.

16. I. Wayan Juniartha, "Activists Resume Opposition to Pornography Bill," JP, March 26, 2010.

17. Tini Tran, "Indonesian Provinces Plan to Ignore Anti-porn Law," AP, March 26, 2010.

18. See Arlina Arshad, "Indonesia to Crack Down on Porn over Ramadan," AFP, August 10, 2010; Kinanti Pinta Karana, 'Indonesian Infotainment 'King,' Gossip Show Host Attempts to Defend Industry," JG, July 23, 2010.

19. See Bagus B. T. Saragih, "Cleric: Sharia Higher than National Law," JP, March 26, 2010.

20. H. Usamah Hisyam, member of parliament, United Development Party, personal communication, Jakarta, July 22, 1999; Muhammad Yunus Yosfiah, information minister, personal communication, Jakarta, June 10, 1999.

21. See, for example, "74,5\% Warga Indonesia Setuju Demokrasi, 5,8\% Ingin Diktator," Sinar Indonesian Baru, August 11, 2014, citing the survey, Kinerja Demokrasi dan Pilpres 2014: Evaluasi Pemilih Nasional, Temuan Survei, 21-26 Juli, 2014 (Jakarta: SMRC, 2014).

22. Presi Mandari, "Indonesian Facebook Mum Wins Hospital Defamation Case," SMH, December 29, 2009.

23. Elske Schouten, "Facebook Group Thwarts Libel Case in Indonesia," NRC Handelsblad, December 31, 2009.

24. "Pennies for Prita Campaign Pulls in Rp 500 Million," JG, December 9, 2009.

25. Schouten, "Facebook Group Thwarts Libel"; Mong Palatino, "Justice in Jakarta," Relativity Online, February 1, 2010, www.relativityonline.com/home/justice-in-jakarta/.

26. Dessy Sagita, "Prita Takes a Firm Stand with Omni over Suit," JG, December 14, 2009.

27. Thamrin Amal Tomagola, quoted in Tifa Asrianti, "Putting in Their Two Cents," JP, December 13, 2009.

28. The country climbed from 114 of 177 in 2013, to 88 of 168 in 2015. Transparency International Corruption Perceptions Index, accessed September 25, 2016, https://www. transparency.org/cpi2014/in_detail. 2009.

29. Norimitsu Onishi, "Corruption Fighters Rouse Resistance in Indonesia," NYT, July 25,

30. Aleksius Jemadu, "Transnational Activism in Indonesia," in Transnational Activism in Asia: Problems of Power and Democracy, ed. Nicola Piper and Anders Uhlin (London: Routledge, 2004), 157; Sofie Arjon Schütte, "Government Policies and Civil Society Initiatives against Corruption," in Bünte and Ufen, Democratization in Post-Suharto Indonesia, 86-90. 
31. Jeremy Mulholland, “Indonesia's Anti-corruption Drive," New Mandala, July 24, 2016.

32. Emil Bolongaita, "An Exception to the Rule? Why Indonesia's Anti-corruption Commission Succeeds Where Others Don't-a Comparison with the Philippines's Ombudsman," U4 Issue 4 (August 2010): 14, https://www.u4.no/publications/an-exception-to-the-rule-whyindonesia-s-anti-corruption-commission-succeeds-where-others-don-t-a-comparison-withthe-philippines-ombudsman.

33. Onishi, "Corruption Fighters Rouse Resistance."

34. "Indonesia, Thailand: Asia's Most Corrupt," Bangkok Post, April 9, 2009.

35. Aristides Katoppo, interview with author, Jakarta, July 11, 2009.

36. Christian von Luebke, "The Politics of Reform: Political Scandals, Elite Resistance, and Presidential Leadership in Indonesia," Journal of Current Southeast Asian Affairs 2, no. 1 (2010): 90.

37. Salim Osman, "KPK Plot Wiretap Played to Nation," ST, November 4, 2009; Tom Wright and Yayu Yuniar, "Tapes of Alleged High-Level Conspiracy Electrify Indonesia," WSJ, November 4, 2009.

38. "Gerakan 1.000.000 Facebookers Dukung Chandra Hamzah \& Bibit Samad Riyanto," accessed September 25, 2016, https://www.facebook.com/group.php?gid=169178211590, cited in von Luebke, "Politics of Reform."

39. Tom Allard, "Bank Claims Smudge Yudhoyono's Clean Image," Age, November 21, 2009; Anissa S. Febrina, “The Animal Kingdom Rules,” JP, November 18, 2009.

40. "A Groundbreaking Move?," JP, December 2, 2009.

41. Carl Giacomo, "Indonesia's Corruption Fighters in the Fight of Their Lives," NYT, February 20, 2015.

42. David Adam Stott, "Indonesia's Elections of 2014: Democratic Consolidation or Reversal?” Asia-Pacific Journal 12, no. 10 (March 2014), https://apjjf.org/2014/12/10/David-AdamStott/4087/article.html.

43. Yenni Kwok, "The 'Jokowi Effect' Could Be the Most Important Thing in Indonesia's Elections," Time, April 9, 2014.

44. Marcus Mietzner, "Indonesia's 2014 Elections: How Jokowi Won and Democracy Survived," Journal of Democracy 25, no. 3 (October 2014): 120.

45. "Garbage In, Garbage Out," Tempo, July 7-13, 2104.

46. “Obor Rakyat Sebarkan Berita Jokowi Pro Kristen," Tempo.Co, June 4, 2014, https:// pemilu.tempo.co/read/news/2014/06/04/269582378/Obor-Rakyat-Sebarkan-Berita-JokowiPro-Kristen.

47. "Manuver Para Jenderal di Balik Bocornya Surat DKP Prabowo," TV One, June 12, 2014.

48. MetroTV is owned by the National Democrat party chair, Surya Paloh. See Edward Aspinall, "Indonesia on the Knife's Edge," Inside Story 17 (June 2014), http://insidestory.org. $\mathrm{au} /$ indonesia-on-the-knifes-edge/.

49. Ben Bland, "Indonesia Strongman Prabowo Closes Gap on Rival Ahead of Poll," FT, June 24, 2014.

50. See, for example, Ken Miichi, "Democratization and the Changing Role of Civil Society in Indonesia," Middle East Institute, October 13, 2015, http://www.mei.edu/content/map/ democratization-and-changing-role-civil-society-indonesia; Edward Aspinall, "Indonesian Democracy Stronger, but Not Yet out of the Danger Zone," East Asia Forum, July 13, 2014.

51. Aspinall, "Indonesian Democracy Stronger."

52. Yoes C. Kenawas and Fitriani, "Indonesia's Next Parliament: Celebrities, Incumbents and Dynastic Members?," East Asia Forum, May 31, 2013.

53. Nithin Coca, "Indonesia’s Anti-corruption Fight," Diplomat, February 8, 2016.

54. Ibid.

55. Quoted ibid.

56. Quoted ibid.

57. Joe Cochrane, "A Corruption Scandal with a Silver Lining," NYT, December 18, 2015.

58. Joe Cochrane, "Top Indonesian Official, Long Seen as Untouchable, Gets Prison for Graft," NYT, April 24, 2018; John McBeth, "Indonesia's Mr Teflon Goes Free Again,"AT, October 5, 2015, http://www.atimes.com/article/indonesias-mr-teflon-goes-free/.

59. "Shady Organization Targets Tempo," JP, March 12, 2015.

60. US Department of State, Country Reports on Human Rights Practices for 2015: Indonesia (Bureau of Democracy, Human Rights, and Labor, US Department of State, April 13, 2016), https://www.state.gov/documents/organization/252977.pdf. 
61. "Jokowi Perintahkan Polri Hentikan Kriminalisasi terhadap KPK dan Pendukungnya," Kompas.com, March 5, 2015, https://nasional.kompas.com/read/2015/03/05/21095941/ Jokowi.Perintahkan.Polri.Hentikan.Kriminalisasi.terhadap.KPK.dan.Pendukungnya.

62. Haeril Halim, "KPK Law Amendment Delayed," JP, February 23, 2016.

63. "Jokowi Dukung Penguatan KPK, Reformasi Kejaksaan dan Polri," Kompas.com, December 1, 2016, https://nasional.kompas.com/read/2016/12/01/12502261/jokowi.dukung.pen guatan.kpk.reformasi.kejaksaan.dan.polri.

64. John McBeth, "All Eyes on Indonesia’s Identity Card Scam," AT, August 2, 2017.

65. "KPK Tells Setya Novanto to Get Over Rejected Pretrial Motion," Tempo.co, December 15, 2017, https://en.tempo.co/read/news/2017/12/15/055914130/KPK-Tells-Setya-Novantoto-Get-Over-Rejected-Pretrial-Motion; "President Warns Police against Criminalizing KPK Leaders," JP, November 10, 2017.

66. Dony Indra Ramadhan, "Apa Kabar Setya Novanto di Lapas Sukamiskin?" detikNews, May 8, 2018, https://news.detik.com/berita/d-4010811/apa-kabar-setya-novanto-di-lapas-sukamiskin.

67. "KPK Khawatir RUU KUHP Ditunggangi \& Lemahkan Pemberantasan Korupsi," Merdeka.com, May 30, 2018, https://www.merdeka.com/peristiwa/kpk-khawatir-ruu-kuhpditunggangi-lemahkan-pemberantasan-korupsi.html.

68. Alexis de Tocqueville, "Liberty. Trade. Dublin (7th July)," in Journeys to England and Ireland, ed. J. P. Mayer, trans. George Lawrence and K. P. Mayer (New Brunswick, NJ: Transaction, 1988), 116.

69. "Survey of Indonesian Public Opinion," International Republican Institute, June 19-27, 2013, http://www.iri.org/sites/default/files/2013\%20September\%2017\%20Survey\%20of\%20 Indonesian\%20Public\%20Opinion\%2C\%20June\%2019-27\%2C\%202013.pdf.

70. Chappell H. Lawson, Building the Fourth Estate: Democratization and the Rise of a Free Press in Mexico (Berkeley: University of California Press, 2002), 139.

71. Ibid., 151.

72. Rodrigo Aguilera, "Democracy and the Mexican Disease," Huffington Post, January 22, 2015, https://www.huffingtonpost.com/rodrigo-aguilera/democracy-and-the-mexican_b_ 6525626.html.

73. Ibid.

74. Elisabeth Malkin, "Purchase by Mexican President Is under Scrutiny," NYT, February 3, 2015; Paulina Villegas and Frances Robles, "Deals Flow to Contractor Tied to Mexican President," NYT, July 30, 2015.

75. Lev Garcia and Mark Stevenson, "Ruling Party Sees Stinging Defeats in Mexican Elections," AP, June 6, 2016.

76. Danielle Cuddington and Richard Wile, "Declining Ratings for Mexico's Peña Nieto," Pew Research Center: Global Attitudes and Trends, August 27, 2015.

77. Azam Ahmed, “'A Bad Joke’: Corruption Battle Stalls in Mexico, Watchdog Says," NYT, December 2, 2017.

78. Elisabeth Malkin, “Mexico’s Attorney General Resigns under Pressure,” NYT, October 16, 2017.

79. “The Victory of Andrés Manuel López Obrador Starts a New Era in Mexico," Economist, July 2, 2018, https://www.economist.com/the-americas/2018/07/02/the-victory-of-andresmanuel-lopez-obrador-starts-a-new-era-in-mexico.

80. Lise Garon, Dangerous Alliances: Civil Society, the Media \& Democratic Transition in North Africa (London: Zed Books, 2003), 1, 154-67.

81. Shelley Deane, Transforming Tunisia: The Role of Civil Society in Tunisia's Transition (London: International Alert, 2013), https://www.international-alert.org/sites/default/files/publications/ Tunisia2013EN.pdf.

82. Safa Ben Said, "In Tunisia, Press Freedom Erodes amid Security Fears," CPJ, October 27, 2015.

83. “2016 Press Freedom Index," Reporters without Borders, April 20, 2016, https://rsf. org/en/ranking/2016.

84. Mischa Benoit-Lavelle, “'Sheratongate' Shakes Tunisian Ruling Party," Al-Monitor, January 13, 2013.

85. Quoted in Thomas Bass, "A Woman Blogger's Scoop Helped Save Tunisia from Islamists," Daily Beast, April 6, 2014, https://www.thedailybeast.com/a-woman-bloggers-scoop-helpedsave-tunisia-from-islamists. 
86. Quoted ibid.

87. "History of Corruption: Different Generations of Chaebol Implicated in Scandals," Hankyoreh, December 6, 2016.

88. "Donations to Mir, K-Sports Need Scrutiny," Korea Times, September 23, 2016; Elizabeth Shim, "South Korea Leader's Friend Had Access to Secrets, Relayed 'Messages' from Late Mom," UPI, October 26, 2016.

89. Quoted in Choe Sang-hun and Motoko Rich, "How South Korea Ended Up on the Brink of Ousting a President," NYT, January 3, 2017.

90. Yoonjung Seo, "The South Korean Political Scandal Started with a Card Game in Macau," WP, November 6, 2016. 2016.

91. Chung Hyun-chae, "Scandal Unveils Choi Soon-sil's ‘Boy Toy,” Korea Times, October 30, 2016.

92. Choe Sang-hun, "Key Figure in Scandal's Latest Twist Is a Puppy," NYT, December 10,

93. "Donations to Mir." 2016.

94. Jung Min-ho, "How the Choi Soon-sil Scandal Unfolded," Korea Times, January 8,

95. Choe Sang-hun, "South Korea's Blacklist of Artists Adds to Outrage over a Scandal," NYT, January 13, 2017.

96. Choe Sang-hun, "Korea Vote Puts Nation in Limbo," NYT, December 10, 2016; Choe and Rich, "How South Korea Ended Up."

97. Se-Woong Koo, "The Choi Soon-sil Gate: The Saddest Political Drama Ever Told," Korea Exposé, November 1, 2016.

98. James Seo, "James Seo's Answer to Why Are South Koreans So Angry with Their President That 1 Million Protesters Took to the Street," Quora.com, December 8, 2016, https:// www.quora.com/Why-are-South-Koreans-so-angry-with-their-President-that-1-millionprotesters-took-to-the-street.

99. "Restoring Trust in South Korea," editorial, NYT, December 10, 2016.

100. Anna Fifield, "Here Is Everything You Need to Know about South Korea's Extraordinary Presidential Scandal," WP, November 3, 2016.

101. Quoted in Choe and Rich, "How South Korea Ended Up."

102. Howard Tumber and Silvio R. Waisbord, "Introduction: Political Scandals and Media Across Democracies, Volume I," American Behavioral Scientist 47, no. 8 (2004): 1031-32, 1035.

103. Silvio Waisbord, "Scandals, Media and Citizenship in Contemporary Argentina," American Behavioral Scientist 25, no. 3 (2004): 1072-98.

104. Pippa Norris, A Virtuous Circle: Political Communications in Post-industrial Democracies (Cambridge: Cambridge University Press, 2000), 19.

105. Sheila Coronel, "Corruption and the Watchdog Role of the News Media," in Public Sentinel: News Media \& Governance Reform, ed. Pippa Norris, 111-36 (Washington, DC: World Bank, 2010).

106. Sheila Coronel, "People Power Fatigue: Democracy and Disillusionment in the Philippines," Friday Forum lecture, Center for Southeast Asian Studies, University of WisconsinMadison, April 18, 2008.

107. Norris, Virtuous Circle; J. Samuel Valenzuela, "Democratic Consolidation in Post-transitional Settings: Notion, Process, and Facilitating Conditions," in Issues in Democratic Consolidation: The New South American Democracies in Comparative Perspective, ed. Scott Mainwaring, Guillermo O’Donnell, and J. Samuel Valenzuela (Notre Dame, IN: Notre Dame Press: 1992), 62.

108. In Ukraine, the brutal murder of a journalist critical of the regime, Georgy Gongadze, in 2000 became a potent symbol to mobilize the democratic opposition. C. J. Chivers, "Yushchenko Steps Out Presidentially; Rival Grumbles," NYT, December 30, 2004; Tom Warner, "Ukraine Journalists Tell Government of Fear on the Job," WSJ Europe, September 28, 2000; Charles Clover, “Ukraine's President 'Linked to Missing Journalist,' MPs Told," FT, December 13, 2000.

109. Bambang Harymurti, interview with author, Jakarta, July 4, 2009.

110. Goenawan Mohamad, Sidelines: Thought Pieces from "Tempo" Magazine, trans. Jennifer Lindsay (Jakarta: Lontar, 1994), 73.

111. See Jeffrey A. Winters, Oligarchy (Cambridge: Cambridge University Press, 2011). 
112. Ross Tapsell, Media Power in Indonesia: Oligarchs, Citizens and the Digital Revolution (London: Rowman \& Littlefield, 2017); Ariel Heryanto and Stanley Yoseph Adi, "The Industrialization of the Media in Democratizing Indonesia," Contemporary Southeast Asia 23, no. 2 (2001): 327-55.

113. One observer noted that Indonesia's news media might best be described as a "multioligarchic free press." Anonymous reviewer, Cornell University Press, July 25, 2017. 
